TAD, C. 39/S. 67, 2020, s.9-52

\title{
MALATYA DEMİR ÇAĞI ARAŞTIRMALARI 2018
}

\author{
MALATYA IRON AGE RESEARCH 2018
}

\section{Sevgi DÖNMEZ*}

\author{
Makale Bilgisi \\ Başvuru: 12.06.2019 \\ Kabul: 11.10 .2019
}

\author{
Article Info \\ Received: June 12, 2019 \\ Accepted: October 11, 2019
}

\section{Özet}

2017 yılında başlatılan arkeolojik yüzey araştırmasının devamı niteliğindeki 2018 arkeolojik yüzey araştırması, Malatya İli, Yeşilyurt ve Battalgazi İlçelerinde, jeomorfolojik anlamda farklılık gösteren iki bölgede, Malatya Ovası ve Malatya Dağlarını içine alan saha üzerinde yürütülmüş̧ür. Malatya Ovası'nda yürütülen araştırmalar sırasında kısmen Karakaya Baraj suları altında kalan Alibey Höyük, Tohma Havzası'nda Pınarkolu-Sivri Tepe Mevkii, Kürdonun Bükü Höyük, Avşaroğlu Nekropol Alanı, Sultansuyu Havzası üzerinde Örentepe Höyük ve Tepecik Mevkii'nde Demir Çăğ'nın her üç döneminin de temsil edildiği seramik parçaları bulunmuştur. Araştırmanın ikinci bölümünü oluşturan Malatya Dağları yüzey araştırması, deniz seviyesinden yaklaşık 1400-2000 m yükseklikte yer alan ve halen günümüzde yayla kültürleri tarafindan kullanılan sahada gerçekleştirilmiştir. Araştırmalar sırasında Erken Demir Çă̆ ve Orta Demir Çağı'nda yoğun olarak kullanıldı̆̆ını düşündüğ̈̈müz altı arkeolojik alanda savunma yapıları ve seramik parçaları tespit edilmiştir. Beypınar Tepe, Kilise Tepe, Seyituşağı Kale Arkeolojik Alanı, Meydan Kalesi, Cihan Kalesi ve Aşăğköy/Kalebaşı arkeolojik alanları, Demir Çă̆ı'nda Doğu Anadolu Bölgesi'nde sıklıkla kullanılan, doğal sarp kayalık alanların, taş örgü duvarlarla birleştirilmesiyle oluşturulan savunma amaçl yerleşimlerin birer tipik örneği durumundadır. Malatya Dağlarl üzerinde, herhangi bir mimari kalıntı gözlemlenemeyen, yayla kültürleri tarafindan kutsal kabul edilen Üçgöze/Ziyaret Tepe Mevkii'nde Demir Çă̆ı seramik formunu yansitan seramik

* Dr. Öğr. Üyesi, İnönü Üniversitesi, Fen Edebiyat Fakültesi, Arkeoloji Bölümü, sevgi.donmez@inonu.edu.tr 
parçası bulunmuştur. Malatya Dağları ve Malatya Ovası üzerinde tespit edilen arkeolojik alanlardaki seramikler, Yukarı ve Aşağ Fırat Havzası, Yukarı Dicle Bölgesi, Kuzeydoğu ve Orta Anadolu, Suriye ve Kuzey Mezopotamya'da yürütülen kazılar ve yüzey araştırmalarından toplanan seramikler ile karşılaştırılmış ve bölgeler arası etkileşimi ortaya koyan önemli sonuçlar elde edilmiştir.

Anahtar Kelimeler: Malatya Dağları, Malatya Ovası, Yüzey Araştırması, Seramik, Demir Çă̆l

\section{Abstract}

Archaeological survey in 2018 which can be considered as a continuation to the archaeological survey in 2017 is conducted on Malatya Province's Yeşilyurt and Battalgazi districts, an area which two regions have differences in regards to geomorphology: Malatya Plains and Malatya Mountains. During the research conducted on Malatya Plains, ceramic sherds which are representing all three periods of Iron Age are found on Alibey Höyük which became partially submerged under Karakaya Dam waters; Pınarkolu-Sivri Tepe Area, Kürdonun Bükü Höyük, Avşaroğlu Necropolis Site in Tohma Basin; Örentepe Höyük in Sultansuyu Basin and Tepecik Area. Survey on Malatya Mountains which is the second part of the research is conducted on the area located 1400-2000 meters above sea level which is still actively used today by highland cultures. During the research, defense structures and ceramic sherds which are considered to be largely used during Early Iron Age and Middle Iron Age have been identified from the six archaeological site. Each of the Beypınar Tepe, Kilise Tepe, Seyituşağl Kale Archaeological Site, Meydan Kalesi, Cihan Kalesi and Aşağılköy/Kalebaşı archaeological sites are considered to be typical examples of defensive purpose settlements constructed by combining natural steep cliffs with stone build walls which are largely used in East Anatolian Region in Iron Age. In Üçgöze/Ziyaret Tepe area located upon Malatya Mountains where no archaeological structure are present and highland cultures enshrining the area; a ceramic sherd which is reflecting the Iron Age ceramic form is found. Ceramics identified in archaeological sites on Malatya Mountains and Malatya Plain is compared with ceramics collected from systematic archaeological excavations and surveys conducted in Upper and Lower Euphrates Basin, Upper Tigris Region, Northeastern and Central Anatolia, Syria and Northern Mesopotamia, and significant results were obtained which are revealing interregional interaction.

Keywords: Malatya Mountains, Malatya Plain, Survey, Ceramic, Iron Age 


\section{Giriş}

T.C. Kültür ve Turizm Bakanlığı, Kültür Varlıkları ve Müzeler Genel Müdürlüğünün izni ile İnönü Üniversitesi Fen Edebiyat Fakültesi Arkeoloji Bölümü tarafından 2017 yılında başlatılan arkeolojik yüzey araştırmasının devamı niteliğindeki 2018 araştırmaları, Malatya İli Battalgazi ve Yeşilyurt ilçelerinde devam etmiştir. 2018 arkeolojik yüzey araştırması, Malatya Ovası'nda ve Malatya Dağları'nın Çat Barajı ve Pütürge İlçe sınırlarına kadar uzanan, yüksek ve engebeli bir sahasında gerçekleştirilmiştir (Fig. 1415). Araştırmalar sırasında, yayla kültürleri ve Malatya Ovası arkeolojik yerleşimler arasındaki ilişkilere 1şık tutacak 14 arkeolojik merkezde, Demir Çağı'na ait seramik materyal bulunmuştur. Elde edilen veriler bir önceki dönemin araştırma sonuçları ile birlikte değerlendirilmiş ve bu kapsamda yeni bulunan Demir Çağı merkezlerindeki seramik materyal, bölgede daha önceki yıllarda yapılan araştırma ve kazı sonuçlarından elde edilen seramik materyallerle karşılaştırılması yapılmıştır. Şüphesiz ki yeni bulunan Demir Çağı merkezleri, bulundukları konum itibariyle dönemin politik ve ekonomik anlamda önemine 1şık tutacak veriler sunmuş̧tur.

Malatya Bölgesi'nde gerçekleştirilen araştırmalar ve kazılar genel anlamda, Malatya Ovası ve Malatya Ovası'na uzanan dağların etekleri ile sınırlı kaldığından dolayı bu bölgenin yayla kültürleri ve bu kültürlerin ova yerleşimleri ile etkileşimini ortaya koyacak çalışmalar yetersizdir. Bölgenin Demir Çağı araştırmalarına 1şı tutacak en önemli sonuçlar, Arslantepe'de gerçekleştirilen sistemli kazılar ile Karakaya ve Keban Barajı kurtarma kazıları ve araştırmalarından elde edilmiştir. Yukarı Fırat Bölgesi'nde Demir Çağ1 ile ilgili en sistemli bilgiler, Korucutepe (Winn 1980: 155-175), Arslantepe (Manuelli, 2011, 2012a, 2012b Frangipane vd. 2018), Köşkerbaba (Bilgi 1980, 1981, 1982, 1983, 1984, 1985, 1987), Değirmentepe (Esin 1980, 1981, 1982, 1984; Esin ve Arsebük 1983; Esin ve Harmankaya 1985, 1986) ve Norşuntepe (Hauptmann 1971, 1972, 1974, 1976, 1982) kazılarından gelmektedir. Ayrıca Yukarı Fırat ve Orta Firat Havzası'nda gerçekleştirilen yüzey araştırmalarından, Demir Çağı yerleşimlerinin mekânsal dağılımı ve birbirleriyle ilişkilerinin ortaya konmas1 açısından, önemli sonuçlar elde edilmiştir (Özdoğan 1977; Serdaroğlu 1977; Russell 1980: 35-39; Sevin 1987, 1988). 2003-2005 y1lları arasında gerçekleştirilen yüzey araştırmasıi Malatya Ovası'nda yer alan Demir Çağı yerleşimlerinin tespitinde önemli olmuştur (Di Nocera 2004, 
2008). Yukarı Dicle Bölgesi (Köroğlu 2002; Roaf ve Schachner 2005; Tekin 2006), Orta Firat Havzası (Blaylock vd. 1990; 112-116; Müller 1999), Kuzeydoğu Anadolu (Parker 1999; Marro ve Özfirat 2003; Konyar 2004; Iş1kl1 ve Erdem 2009; Sagona 2012) ve Orta Anadolu Bölgesi'ndeki (Durbin 1971; Güneri 2002) araştırmalar, Malatya'nın güney-kuzey, doğu-batı doğrultusunda bölgeler arası kültürel etkileşimin kavşak noktasında bulunması nedeniyle, Malatya Bölgesi’ndeki yeni araştırmaların sonuçlarının değerlendirilmesine de önemli katkılar sunmaktadır.

2018 yılında araştırma yapılan Malatya Ovası ve Malatya Dağları'nın büyük bir kısmını kapsayan saha, coğrafi konum olarak güneyde Suriye ve Akdeniz, batıda Orta Anadolu, kuzeydoğuda Yukarı Fırat Bölgesi ve Kuzeydoğu Anadolu'nun yüksek yaylalarına ulaşım sağlayan bir geçiş bölgesi özelliğindedir. Araştırma yapılan saha, Malatya Dağları ve Malatya Ovası'nı kapsayan iki farklı coğrafi bölgeden oluşmaktadır. Malatya Ovası yüksekliği 800-900 m arasında değişen, çeşitli yönlerden gelen akarsularla beslenen, doğu, batı ve güneyinde Toroslar ile çevrelenmiş, Erken Neolitik Dönem ile birlikte sürekli yerleşimlerin kurulduğu, Doğu Anadolu'nun en büyük havzalarından birisidir (Yakar 2007: 336; Dönmez 2019: 45). Malatya Dağları, Malatya Ovası'nın güneyinde, güneybat1-kuzeydoğu yönünde uzanan, en yüksek noktası 2545 metreyi bulan, morfolojik anlamda dalgalı ve çeşitli yönlerden gelen akarsularla parçalanmış bir yapıya sahiptir (Karadoğan 2001: 28; Tonbul ve Siler 2017: 463). Malatya Dağları üzerinde yer alan Karlık, Bürücek, Rafa, Kızıltarla, Subatan, Meydan (Mendol), Gevrik, Şekerpınar, Cihan, Taney, Sin Ali, Uzunpınar, Kurnaz, Yedi Oluk, Fadıl, Kömür, Üçpınar, Kubbe Dağı, Halikan, Alikan, Birsor, Zeyno gibi çok sayıda yayla, hayvancılık açısından önemli, akarsuların ve meşe ormanlarının bulunduğu yerlere yakın konumdadır. Yoğun otlak alanların yanında özellikle yüksek bölgelerde ardıç, alıç, meşe, yabani armut (pyrus pyraster), yabani erik (prunus spinosa), yabani badem, ceviz, yabani incir, trüf mantarı (tuber), kenger (gundelia), dağ kekiği, geven (astragalinae), dağ reyhanı (cibreska), vadilik alanlarda, saz, kızılcık, kuşburnu, iğde, yabani çilek ( fragaria vesca), 1şkın (rheum ribes), çiriş otu (asphodelus) gibi vahşi bitkiler ve meyveler yetişmektedir. Bu vahşi bitkiler arasında alıç, yabani armut, yabani erik, yabani badem, ceviz, yabani incir, kuşburnu, iğde, yabani çilek, kızılcık, trüf mantarı, kenger, dağ kekiği, dağ reyhanı, ş̧kın, çiriş otu günümüzde mevsimlik olarak tüketilmekte veya kısmen semt pazarlarında yaş veya kurutulmuş olarak satılmaktadır. Ayrıca sazlardan yapılan hasırlar, 
yakın zamana kadar evlerde ya da çadırlarda zemin örtüsü olarak kullanılmaktaydı. Tarıma uygun araziler oldukça sınırlı olması nedeniyle bölgenin geçim kaynağını hayvancılık oluşturmaktadır. Arazi koşulları nedeniyle kısmi olarak yetiştirilen tarım ürünleri arasında en çok nohut, buğday ve arpa yer almaktadır. Bölgenin oldukça yüksek konumda bulunan otlak alanları, özellikle keçi ve koyun yetiştiriciliği açısından uygun koşullar sunmaktadır. Büyükbaş hayvancılık genelde sürekli yerleşimin olduğu kışlık alanlarda kısıtlı sayıda yapılmaktadır. Yazın serin, kışın ise çok sert iklim koşullarına sahip bu bölge, yarı göçebe kültürler açısından önemli bir yer tutmuştur. Çeşitli akarsularla parçalanan dağların derin vadilerinde, kışın çoğunlukla taştan yapılmış veya taş temelli kerpiç duvarlı evlerden oluşan, kalıcı küçük köyler ve mezralarda yaşayan yöre halkı, Mayıs ayı ortalarından Ekim ay1 sonuna kadar bölgedeki yaylalara göçmekte ve burada hayvancılıkla uğraşmaktadır (Fig. 13). Bölgede son yıllarda gerek politik gerekse sosyo-ekonomik nedenlerle oldukça azalan yaylacılık kültürünü hâlen devam ettiren çok az sayıda aile bulunmaktadır. Malatya Dağları üzerinde yer alan Kubbe Dağı Çad Mevkii, Tepeyurt, İbicek, Puluşağı, Kuyuluk ve Meydan Yaylası maden işlik alanlarında ele geçen demir cevheri ve cürufları, Demir Çağı'nda, bu bölgenin, maden ekonomisinde önemli bir rol oynadığını göstermektedir (Dönmez 2019).

\section{Arkeolojik ve Yazılı Belgeler Işs̆ğında Demir Çağı'nda Malatya ve Çevresi}

Malatya, bulunduğu konum itibariyle hem Güneydoğu hem Orta Anadolu hem de Doğu Anadolu Demir Çağ kültürlerinin buluştuğu bir geçiş bölgesi özelliğinden dolayı, Demir Çağı zaman dizini belirlenirken, politik gelişmeler, maddi kültür kalıntılarının yayılımı aşamaları ve sürekliliği gibi problemleri içeren bölgesel farklılıklar meydana gelmektedir (Dönmez 2019: 45). Bu çalışmada araştırma yapılan alan, özellikle Doğu ve Güneydoğu Anadolu kültürlerinin yayılım alanını oluşturmasından dolayı bu bölgelerin Demir Çağı kronolojik dizini esas alınacaktır. Buna göre Demir Çağı I ya da Erken Demir Çağı (EDÇ), Hitit İmparatorluğu'nun çöküşü ile Urartu Krallı̆̆ı'nın bölgesel politik bir güç olarak ortaya çıktığı dönem arasına (M.Ö. 1200/1150-800) yerleştirilmektedir (Köroğlu 2003: 231; Dönmez 2019: 45-46). Demir Çağı II veya Orta Demir Çağı (ODÇ), Yakındoğu'da aktif iki büyük politik güç olan Urartu Krallığı ve Yeni Assur Krallığı'nın bölgedeki, askeri, siyasi ve sosyo-ekonomik faaliyetlerini içeren dönemi 
kapsamaktadır. Buna göre Malatya ve yakın çevresi için ODÇ M.Ö. 850/800- M.Ö. 650/600 arası döneme yerleştirilmektedir (Ökse 1988: XIX; Khatchadourian 2011: 480-484; Manuelli 2011: 63; Dönmez 2019: 46). Geç Demir Çağı (GDÇ) ya da Demir Çağı III (M.Ö. 645/600-330), Urartu ve Assur Krallıklarının bölgede etkinliklerinin kaybolması ve yıkılması süreci ile Akhamenidlerin bölgede politik kontrolü sağladıkları dönemi içermektedir (Yiğitpaşa 2015: 512-513).

M.Ö. 12. yüzyılın başlarında Hitit İmparatorluğu'nun başkenti Hattušaš'ın yıkılması Eski Yakındoğu ve Anadolu tarihinde sosyo-ekonomik ve politik dinamiklerin değişiminde ve dönüşümünde önemli bir rol oynamıştır (Sagona ve Zimansky: 294). Bu dönemde, Yakındoğu'nun neredeyse büyük bir bölümünde, Geç Bronz Çağı (GBÇ) merkezlerinin çoğunda politik organizasyonun çöküşünün izleri görmek mümkündür. Geç Bronz Çağı'nın sonlarında Yakındoğu'yu etkisi altına alan kurak iklim koşulları, tarıma dayalı üretimdeki azalma ve bölgesel çatışmaların birer sonucu olarak ortaya çıkan göçler, kıtlık, salgın hastalıklar, güvensiz köyler ve şehirler, ticarete dayalı ekonomik ve politik organizasyonların çökmesinde büyük rol oynamıştır (Liverani 2014: 381-382). Polen analizleri sonucunda elde edilen bulgular, Geç Bronz Çağı'nın sonlarında, Doğu Akdeniz Bölgesi'nde, ani iklim değişikliğine ilişkin sonuçlar vermiştir (Finné vd. 2011: 3168). Doğu Akdeniz Bölgesi'nde kurak iklim koşulları ve deprem gibi istikrarsız tektonik hareketler, saraya dayalı politik organizasyonların çöküşünü hızlandırmıştır (Drake 2012). Geç Bronz Çağı'nın sonlarında Anadolu'da kıtlık ve üretim krizine dair bulgular, krali yazışmalara da yansımıştır. Hititler, ülkedeki kıtlık nedeniyle, vassal ülkelerden ve Misır'dan tahıl ithal etmiştir (Bryce 2003: 219-220; Liverani 2014: 382). Tarıma dayalı üretim krizi nedeniyle yerleşik tarım toplumlarının gücünün kırılması, çoğunlukla göçebeliğe dayalı sosyoekonomik yapılanmanın ve yaşam biçiminin öne çıkmasında etkili olmuştur. M.Ö. 12. yüzyılın ilk yarısında, bu değişimin ve yıkımın izleri, hepsinde olmamakla birlikte Levant'ta ve Orta Anadolu'da pek çok Geç Bronz Çağ kentlerinde görülmektedir (Bartl 2001: 383-384). M.Ö. 12. yüzyılda gerçekleşen, büyük göç dalgası ve yıkımdan sonra Yukarı Fırat Bölgesi'ndeki yerleşmelerin devam ettiğini gösteren kanıtlar gerek yazılı gerekse arkeolojik bulgularla desteklenmektedir. Orta Assur krallarından I. Tiglat-pileser'e (M.Ö. 1114-1076) ait belgelerde Milidia ismi geçmektedir. Bu kayıtlardan birinde I. Tiglat-pileser'in, “Hanigalbat Ülkesi'nin isyankâr 
ve itaatsiz kenti Milidia" kenti üzerine sefer düzenlediği ve Milidia Kenti’nin Assur Kralı'na boyun eğdiğini ve yıllık olarak kurşun vermeyi kabul ettiğini öğrenmekteyiz (RIMA 2: 22). I. Tiglat-pileser'e ait bir başka belgede, Assur Kralı'nın “Büyük Hatti Ülkesi'nin kenti Milidia” üzerine sefer düzenlediği ve kentin kralı Allumari'den tribüt aldığı belirtilmektedir. Bu seferden sonra I. Tiglat-pileser "İ̌̌uwa Ülkesi”" ve "Š̆uhmu Ülkesi” ne sefer düzenlemiş, bu bölgede ele geçirdiği esirleri Assur'a götürmüştür (RIMA 2: 43). Hitit'in periferinde yer alan Kuzey Suriye ve Güneydoğu Anadolu'daki kentlerin EDÇ'nın ikinci yarısından itibaren yeniden yapılanma ve politik organizasyonunu yenileme sürecine girdiği anlaşılmaktadır (Mazzoni 2000: 35-41). Arslantepe kazılarında elde edilen sonuçlara göre M.Ö. 12. yüzyılın başlarında "Imparatorluk Kapısı" olarak adlandırılan yapının büyük bir yangınla yıkıldığına dair bulgular elde edilmiştir. Seramik ve radyo-karbon analizlerine göre, bu çöküşten çok kısa bir süre sonra (M.Ö. 1180-1100), büyük bir yangınla çöken "Imparatorluk Kapısı" yapısının hemen üzerine yeni bir kent duvarının inşa edildiği anlaşılmaktadır. Yeni kent duvarı (M159) inşa edildikten sonra, kent kapısı, yeni duvarın hemen içerisinde yer alan yeni bir duvarın (A1278 M1) üzerine inşa edilmiştir. Bu tabakalardan elde edilen radyo-karbon analizlerine göre M.Ö. 1050 civarında, yeni şehir duvarı ve kapısının, muhtemelen Assur saldırısı sonucunda, ikinci bir yangınla yıkıldığı ve yaklaşı 150-200 yıl boyunca yeni şehir duvarı ve kapısının yeniden inşa edilmediği anlaşılmaktadır. Yeni şehir duvarı kalıntılarının bulunduğu yangın tabakasında, çukurlar, barınaklar, sütun delikleri, ocak yerleri dağınık olarak bulunmuştur (Liverani 2012: 330-332). Assur Kralı Asur-bel-kala'nın (M.Ö. 1073-1056) yıllıklarında, Assur Kralı'nın Urartu ve komşularına düzenlediği seferde, kentlerin büyük bir yıkımla yenildiğinden bahsedilmektedir. Bu metnin 12. satırında büyük bir yıkıma uğrayan kentler arasında ${ }^{K U R} m i-i l-d[i \ldots]$ da yer almaktadır (RIMA 2: 97). Liverani, ${ }^{K U R}$ mi-il-d $[i \ldots]$ kelimesini Milidia ile eşitlemiştir. Muhtemelen yeni şehir duvarına ait yangın izleri Asur-bel-kala'nın bölgeye düzenlediği seferin bir sonucudur. Benzer şekilde Tille Höyük kazılarında EDÇ şehir duvarı ve giriş kapısı, Arslantepe yeni şehir duvarı ve şehir kapısı ile çağdaştır. Bu yapıların yıkım sürecinin de benzer tarihlerde gerçekleşmiş olması, Yukarı Fırat Bölgesi'ndeki politik gelişmelerle yakından ilişkili görünmektedir (Summers 2010: 195-198; Liverani 2012: 338-339). Orta Assur Dönemi belgelerinde, ilk defa Asur-bel-kala'nın yıllıklarında Milidia, " $U R U$ " yerine, "KUR" determinatifi ile gösterilmiştir. Bu da Milidia'nın 
bağımsız bir Yeni Hitit Krallığı olma sürecinin aydınlatılması açısından önemlidir.

Arslantepe'de M.Ö. 10. yüzyıldan M.Ö. 7. yüzyılın sonlarına kadar önemli bir kesinti olmadan savunma yapılarının sürekli ve yeniden inşa edildiği anlaşılmaktadır (Frangipane vd. 2018: 4). Assur ve Urartu kaynaklarında, M.Ö. 1070-850 y1lları arasında Milidia ile ilgili herhangi bir bilgiye rastlanmaz. Yazılı kaynakların bu dönemde suskunluğu, Orta Anadolu'yu ve Doğu Akdeniz'i etkileyen genel kriz döneminin, Assur da dâhil, bölgede gecikmeli olarak hissedildiğini ortaya koymaktadır. Yeni Assur Kralları'ndan II. Asurnasipal (M.Ö. 883-859) ve II. Sargon (M.Ö. 721-705) arası dönemde, Milidia/Melid, Assur ve Urartu krallıklarının önemli bir çatışma sahası haline gelmiştir. III. Salmanasar'a ait belgelerde (M.Ö. 858-650), Milidia/Melid Assur'un kontrolüne girdiğini ve Assur'a tribüt ödeyen kent devletleri listesinde yer aldığını öğrenmekteyiz. III. Salmanasar'dan sonra Milidia/Melid, Urartu kralları Minua (M.Ö. 810-780), I. Argišti (M.Ö. 780-756) ve II. Sarduri (756-730) zamanında Urartu hâkimiyeti altına girmiş ve Urartu Krallığı'na tribüt ödemeyi kabul etmiştir. M.Ö. 743 yılında III. Tiglat-pileser'in Urartu ve Arpad koalisyonuna karşı gerçekleştirdiği Kištan Savaşı'nda, Assur karşıtı koalisyonda yer alan Milidia/Melid, yenilgiye uğradıktan sonra tekrar Assur kontrolüne geçer (Bryce 2012: 100-101; Liverani 2012: 339-341; Elayi 2017: 110; Dönmez 2019: 47). Bölgedeki politik istikrarsızlık nedeniyle kent krallıklarının çok çabuk koalisyon değiştirdiği bu dönemde, Milidia/Melid tahtına oturan Tarhun-azi, Assur'a tribüt ödemeyi bırakıp, Muşkili Mita'ya tribüt ödemeye başlaması üzerine II. Sargon, M.Ö. 712 yılında buraya sefer düzenlemiştir. II. Sargon'un yıllıklarında bu seferden, "kalbimde öfkeyle onun kraliyet şehri Meliddu'yu ve onunla birlikte çevresindeki şehirleri, bir çömlek gibi ezdim" diye bahseder. $\mathrm{Bu}$ seferden sonra Milidia/Melid Assur'a bağlı eyalet konumundaki Kummuh'a bağlanmıştır. Kummuh Kralı Mutallu'nun isyanı üzerine M.Ö. 709 yılında II. Sargon bölgeye yeniden sefer düzenlemiştir (Liverani 2012: 341-342; Elayi 2017: 111-112). II. Sargon Dönemi'ne ait belgelerde, II. Sargon'un doğuda ele geçirdiği yerlerden insanları "Suteanlar, ${ }^{1}$ okçular ve savaş̧̧ adamları" bu bölgeye yerleştirdiğini öğrenmekteyiz (Elayi 2017: 111-112).

Akkadça “a-mur-ru-ú” Sumerce “ti-id-nu” “ti-da-nu-um”, Eski Babil Dönemi’nde Ur'da bulunan bir metinde "MAR.TU su-ti-um" kelimesi Heltzer tarafindan Sutean ile 
M.Ö. 7. yüzyıldan sonra Assur'un kontrolü altında bulunan birçok bölge Babil ve Medler tarafından işgal edilmiş, Kızılırmak'a kadar olan bölge, sırasıyla Med ve Pers hâkimiyeti altına girmiştir. M.Ö. 6. yüzyılın ikinci yarısında Malatya, Pers hâkimiyeti altında bulunan Kapadokya Satraplığ 1 içerisinde yer almıştır (Liverani 2014: 560-568; Dönmez 2019: 47).

Geç Bronz Çağı'nın sonunda Anadolu ve Doğu Akdeniz Bölgesi'deki çöküş döneminde, her bölgenin sosyo-ekonomik ve politik dinamikleri bu kriz karşısında, farklı tepkiler geliştirmişlerdir. Hititlerin başkenti Hattušaš'ın yıkılmasından sonra, Hitit periferinde, Hitit kültürünün izleri azalarak da olsa devam etmiştir. Hitit kültürünün EDÇ’da da kısmen devam ettiğini gösteren bulgular Altınova'da Tepecik 2a-2b, Norşuntepe III, Korucutepe J, Malatya Bölgesi'nde Arslantepe III, Pirot Höyük IV ve İmikuşağ1 8-7'de ele geçmiştir (Sevin 1991: 87). Yukarı Fırat Bölgesi'nde EDÇ’nda, GBÇ kültürlerinin kısmen devam ettiğini gösteren bulgular Arslantepe'nin III. tabakasındaki seramik buluntulardan anlaşılmaktadır (Manuelli 2012b: 367). Arslantepe III'de, bölgede önemli kültürel değişimi gösteren, el yapımı, kaba, mineral katkılı, ikinci pişirme izlerinin yaygın olduğu seramik grubu ortaya çıkar. GBÇ’nin üretim tekniği açısından astarlı, açkılı, mineral katkılı iyi malları ve geniş tabakları kaybolur. Sığ ve omuzlu kâseleri, daha derin kâse formunda yapılmaya başlanır ve önceki formunda belirgin biçimde azalma gözlemlenir. Ancak boyunlu küpler hala yaygın bir form olarak kullanılmaya devam eder (Manuelli 2011: 67-70). Tille Höyük'te Hititlerin, “drab ware" denilen, bezemesiz seramik kültürü M.Ö. 1150'lere kadar devam eder (Summers 2010: 197-198). Yukarı Firat Bölgesi'nde Erken Demir Çağı'nın karakteristik formunu oluşturan, yavaş dönen çarkta ya da elde yapılmış "yivli” ya da " yatay oluk bezekli" seramik olarak adlandırılan bu grup, ağız ile omuzları arasında yer alan birden çok

eşitlenmiştir (Heltzer 1981: 1-10). Eski Babil Dönemi'nde İran'dan Suriye içlerine kadar yayılan Arami kökenli bu göçebe topluluklar, M.Ö. 2. binin ortalarına doğru Orta Fırat ve Habur Bölgesi'de etkindi. Mezopotamya'da Orta Assur Dönemi'nde Ahlamu olarak adlandırılan bu göçebe gruplar, kentli nüfustan farklı bir biçimde, mevsimsel olarak, hayvan sürülerini otlatmak için sürekli hareket halinde yaşamakta ve y1llık belli göç yollarını takip etmekteydiler. Şeflik olarak tanımlanan bir yapı içerisinde yer alan bu gruplar, hayvancılığa dayalı kırsal bir ekonomik organizasyon üzerinden yaşamlarını devam ettirmekteydiler. Geç Bronz Çağı'nda Sutean/Sutular bölgesel çatışmalarda paralı asker olarak kullanılmakta ve bölgeler arası ticarette kervanlara klavuzluk etmesi için ücret karşıllı̆ıında tutulmaktaydı (Vidal 2010: 96; Liverani 2014: 432-435). 
yatay yiv bezemelidir. Yivli seramik, kuzeyde Transkafkasya ve Erzurum çevresi, güneydoğu'da Urmiye Gölü'nün batı kıyıları, batıda Fırat Irmağı'nın batı kıyısı ve Toroslar'ın güneyine kadar yayılmıştır (Köroğlu 2002: 454-455; Köroğlu 2003; Köroğlu 2015: 115; Tekin 2006: 155). Yukarı Fırat Bölgesi'nde ilk kez tabakalı bir kazı olarak Norşuntepe'de bulunan bu seramik grubu, tarihlemede bölgesel farkl1lıklar içermekle birlikte EDÇ'ndan M.Ö. 8. yüzyılın başına kadar yayılım gösterir (Bartl 2001: 385). I. Tiglat-pileser'in 50 yıl boyunca Alzi/Alše ve Purulumzi topraklarını elinde tutan 20.000 Muški ve onların 5 kralını Katmuhu Ülkesi'ndeki savaşta yendiğini belirttiği belgeye (RIMA 2: 14) dayanarak, burada geçen Muški'nin Proto-Phyrigler olduğu, bu halkın M.Ö. II. binin sonlarında Elazığ Bölgesi’ne yerleşmiş olabilecekleri sonucu çıkarılmış ve yivli seramik, Muški ile ilişkilendirilmiştir (Sevin 1991). Fakat daha sonradan burada geçen Muški ifadesinin fonetik bir benzerlik olduğu ve ProtoPhyriglerle herhangi bir ilişkisinin olmadığı önerilmiştir (Bartl 1995: 206). Yivli seramiğin kullanımı, Yukarı Fırat Bölgesi'nde Zulümtepe, Genefik ve Habibuşağı gibi ODÇ kalelerinde ele geçmiş olması nedeniyle M.Ö. 8. yüzyılın ortalarına kadar devam ettiği önerilmiş olsa da bu kale yapılarının ODÇ tabakalarının EDÇ tabakaları ile karışmış bir kontekst içerisinde olduğu düşünülmektedir (Erdem 2012: 113). Yukarı Firat Bölgesi'nde Karakaya Baraj Bölgesi'nin esas seramik tipini oluşturan tek renkli, kaba, çoğunlukla el yapımı, siyah, kırmızımsı kahverengi seramik ODÇ'de yaygın olarak görünmeye başlar (Ökse 1988: XIX, Manuelli 2011: 68). Karakaya Baraj Bölgesi'nin boyalı seramik grubunu oluşturan düz yüzey üzerine siyah veya kırmızımsı kahverengi linear veya konsantrik daire bezemeli örnekler EDÇ ve ODÇ'de Arslantepe, Köşkerbaba, Değirmentepe, Kaleköy yerleşimlerinde, Kuzeydoğu Anadolu'da EDÇ'de Büyükardıç'ta bilinmektedir (Manuelli 2011: 69; Manuelli 2012a: Fig. 4.10; Ökse 1988: Abb. 601-626; Şenyurt 2005: 542, Fig. 84). Orta Assur ve Yeni Assur döneminin tipik seramik formunu oluşturan "fine carinated bowl" olarak adlandırılan basit ağız kenarlı, omuzları belirginleştirilmiş, bazen keskinleştirilmiş, omurgalı, dipleri düz veya halka biçimli olan seramik formları Yukarı Dicle Bölgesi'nde EDÇ'de yaygın olarak karşımıza çıkar. ODÇ’da ise bu bölgede bu form azalarak devam eder (Köroğlu 2002: 453). "Carinated bowl" tipi seramik Yukarı Fırat Bölgesi'nde Arslantepe III'de bilinen bir formdur (Manuelli 2011: 68). Omurgalı seramik tipi Kuzeydoğu Anadolu'da ODÇ'da ve GDÇ'da kullanılmaya devam eder. Kiremit 
tonlarında kahverengi, bazen kırmızımsı kahverengi astarlı, kaba ya da orta derecede kaba yapılmış, bazen yüzeyi açkılanmış, sırtı keskinleştirilmiş küpler ODÇ ve GDÇ'da Karakaya Baraj Bölgesi ve Kuzeydoğu Anadolu'daki yüzey araştırmaları ve kazılardan bilinmektedir (Ökse 1988: XIX; Parker 1999).

Yukarı Fırat Bölgesi'nde EDÇ'den itibaren ortaya çıkan yeni seramik formları, politik ve sosyo-ekonomik gelişmeler sonucunda göçler ve toplu nüfus aktarımı ile bölgeye yerleşen yeni toplulukların, yerel dinamikler yanında, kendi kültür öğelerini de harmanlayarak kullandığını göstermektedir. Nitekim Malatya ve Elazığ Bölgesi, Demir Çağı'nda önemli iki politik güç olan Assur ve Urartu'nun periferini oluşturması nedeniyle, bu bölgelerin nüfus aktarımı yoluyla kontrol altında tutulmaya çalışıldığını, Urartu ve Assur belgelerinden öğrenmekteyiz (Çilingiroğlu 1983: 316; Elayi 2017: 111-112). Malatya Bölgesi, EDÇ'den GDÇ'nin sonlarına kadar, göçler, toplu nüfus aktarımları ve politik nedenlerle bölgeler arası etkiye oldukça açık kültürel öğeleri içermektedir. Doğu, Güneydoğu Anadolu, Suriye ve Kuzey Irak'a lokalize edilen bölgelerde, Orta Assur ve Yeni Assur Dönemi belgelerinde, "Muški" (RIMA 2: 14), "Ahlamû-Arami” (RIMA 2: 149; RIMA 3: 35), "Lullu"1 (RIMA 2: 248), "Sutu/Suhu” (RIMA 2: 38, 98, $149,180,212)$ isimli göçebe kabilelere karş1 sık sık seferler yapıldığı ve bunlardan tribüt alındığı, bazı durumlarda da bu göçebe kabilelerin zorunlu göçe tabi tutulduğu anlaşılmaktadır.

\section{Malatya Demir Çağı Araştırmaları: Seramik Bulguların Değerlendirmesi}

2018 yılında gerçekleştirilen arkeolojik yüzey araştırması neticesinde Malatya Ovası üzerinde yer alan Alibey Höyük, Sivritepe, Kürdonun Bükü Höyük, Avşaroğlu Nekropolü, Örentepe Höyük, Tepecik ve Sarılık Tepe'de Demir Çă̆g'na ait seramik materyal tespit edilmiştir (Fig. 14).

Alibey Höyük, Battalgazi İlçe sınırları içerisinde Hasırcılar Köyü, Alibey Mevkii'nde yer alan, deniz seviyesinden 686 m. yükseklikte bulunan, kısmen Karakaya Barajı suları altında kalmış bir yerleşimdir. Karakaya Barajı sularının mevsimsel nedenlerle azalması neticesinde, yılın belirli

1 Lullu halkı, Orta Assur ve Yeni Assur Dönemi’nde Zeribar Gölü ile Halep Bölgesi’ni de içine alan bölgede yaşayan, dağınık göçebe gruplardan oluşan bir kavim (Taş ve Adalı 2015). 
dönemlerinde höyüğün büyük bir kısmı su yüzeyine çıkmaktadır. Alibey Höyük yerleşiminin bir kısmı sular altında kalmış olduğundan, höyügün ebatları tam olarak anlaşılamamıştır. Alibey Höyük yüzeyinde toplanan seramik materyal arasında, açık sarımsı portakal renginde astarlı, kalın cidarlı, kaba kum, mika ve saman katkılı, kötü pişirilmiş, el yapımı, dışa kalınlaştırılmış ağız kenarının altında parmak baskı bezemeli küp parçası (Fig. 1: 1), Köşkerbaba (Ökse 1988: Abb. 1108) ve Değirmentepe'de (Esin ve Arsebük 1983: Res. 6.6,16) ODÇ’na tarihlendirilen küp formları ile benzerdir; Muhtemelen büyük bir küpe ait olan, açık gri renkte astarlı, kaba kum ve saman katkıll, açkılı, parmak baskı bezemeli, kötü pişirilmiş, el yapımı amorf gövde parçası (Fig. 1: 2), Karakaya Baraj Bölgesi'nde Köşkerbaba (Bilgi 1987: Lev. 148, A278; Ökse 1988: Abb. 1117) ve Değirmentepe'de (Ökse 1988: Abb. 1097), Keban Baraj Bölgesi'nde Elazı̆̆ Değirmentepe Höyük'te (Duru 1979: Lev. 5. 6) ODÇ'na ait büyük küpler üzerine yapılan parmak baskı bezemeleri aynı stilde yapılmıştır. Kuzey Suriye etkili, ağız kenarının iç kısmında paralel oluk bezemeli, kaba kum, mika ve saman katkıl1, iyi pişirilmiş çanak (Fig. 2: 1), Tell Afiş’te Demir Çağı'na ait, ağız kenarının iç kısmı oluklu ve omurgalı kâselerle benzer formdadır (Oggiano 1999: 398, Fig. 7-9). Ağız kenarının iç kısmı oluklu, omurgalı kâse formları, Yukarı Dicle Bölgesi'nde Üçtepe'de Orta Assur Dönemi'nde yaygın olarak kullanılan, Yeni Assur Dönemi tabakalarında ise azalarak devam eden "Assur mallarl" olarak adlandırılan "carinated bowl" tipi kaplarda sıklıkla kullanılan bir formdur (Köroğlu 2002: 453, Res. 4. 1). Ninive kazılarında EDÇ’na tarihlendirilen bir başka "carinated bowl" tipi seramik, Alibey Höyük'te ele geçen çanak ile oldukça benzer formdadır (Anastasio 2010: 176, Lev. 50.3). Alibey Höyük'te “carinated bowl” tipi omurgalı kâse formlarına örnek teşkil edecek, açık renkte, kötü pişirilmiş, omuzları keskinleştirilmiş sığ kâseler (Fig. 2: 2-3), Lidar Höyük'te (Müller 1999: 420, Abb. 10. AB08), Arslantepe III'de (Manuelli 2012a: 456, Fig. 1. 6-7) EDÇ’nda, Değirmentepe, Şemsiyetepe ve Kaleköy yerleşimlerinin ODÇ tabakalarında (Ökse 1988: Abb. 230-237, 239), Yukarı Dicle Bölgesi’nde Üçtepe'de 7-8. yapı katlarında (Köroğlu 2002: Res. 5. 1-2) iyi bilinmektedir. Alibey Höyük'te ele geçen kötü pişirilmiş, el veya çark yapımı bu örnekler (Fig. 2: 2-3), Assur ve Arami etkileşimi nedeniyle Arami göçebeleri tarafından Yukarı Fırat Bölgesi'ne kadar taşınmış olmalıdır (D'Agostino 2009). Alibey Höyük'te "carinated bowl" tipi kâse formunu en iyi temsil eden örneğin (Fig. 4: 5) benzerleri, Lidar Höyük’te EDÇ (Müller 1999: Abb. 
15.AB22), Arslantepe II (Manuelli 2013: 389, Fig. 6.5), Değirmentepe ve Kaleköy'de (Ökse 1988: Abb. 278-279), ODÇ'na tarihlenen tabakalarda ele geçmiştir. Alibey Höyük'te ele geçen kalınlaştırılmış ağız kenarlı, ağız kenarının iç kısmı, muhtemelen kapak konulsun diye oluklu yapılmış dar ağızlı çömlek (Fig. 2: 4), Suriye'de Tell Afiş (Oggiano 1999: Fig. 6.5), Tell Şeyh Hassan (Schneider 1999: Abb. 8.2) yerleşimlerinin Demir Çağ tabakalarında ele geçmiştir. Kuzeydoğu Anadolu'da ağız kenarının iç kısmı oluklu kap formları Büyükardıç'ta (Şenyurt 2005:505, Fig. 66.4), Arslantepe III'te (Manuelli 2013: Fig. 5.11) ve Lidar Höyük'te (Müller 1999, Abb. 8. AE02) EDÇ'nda bilinen bir formdur. Alibey Höyük'te ele geçen ağız kenarı kalınlaştırılmış kısa boyunlu kadeh (Fig. 3: 1), Erzurum-Pulur'da (Iş̧1klı ve Erdem 2009: Fig. 14.4) ve Lidar Höyük'te (Müller 1999: Abb. 14.CB04) EDÇ'nda, Değirmentepe'nin (Ökse 1988: Abb. 894) ODÇ tabakalarında ele geçen örneklerle aynı formda yapılmıştır. Alibey Höyük'ün bir başka kısa ve düz boyunlu kadeh formu (Fig. 3: 2), Korucutepe (Winn 1980: Pl. 54.7) ve Büyükardıç'ta (Şenyurt 2005: 491, Fig. 59.3) EDÇ tabakalarından bilinmektedir. Alibey Höyük'te EDÇ'nı temsil eden bir başka buluntu, boynu içe kavisli, yoğun kum ve mineral katkılı, çark yapımı testi (Fig. 3: 3), Van/Uncular Nekropolü (Belli ve Konyar 2003: 32, Çiz. 23.2-3) ve ErnisEvditepe Nekropolü'nde (Konyar 2004: 507, Lev. CII.4) bulunan testi örnekleri ile benzer formda yapılmıştır. Alibey Höyük'te GDÇ'nı temsil eden yoğun mineral ve kum katkılı, açık sarımsı portakal renginde, ağız kenarının iç kısmı kapak konması için oluklu yapılmış kavanoz tipi seramik parçası (Fig. 3: 4), EDÇ'nda İmikuşağı'nda (Sevin ve Köroğlu 1985: Res. 6.a), ODÇ'nda Değirmentepe'de (Esin ve Arsebük 1983: Res. 6.15), GDÇ’nda Tasmasor'da (Şenyurt vd. 2011: 250, Fig. 36.346, 348) ve Bayburt/Kelkit yüzey araştırmasından (Parker 1999: Fig. 2.7) tespit edilen kavanozlarla benzer form özellikleri göstermektedir. EDÇ'na tarihlediğimiz düz boyunlu, kötü pişirilmiş, kum, şamot ve saman katkılı, el yapımı kadeh formu (Fig. 4: 1), Büyükardıç'ta (Şenyurt 2005: 475, Fig. 51.2-3), Van Muradiye yüzey araştırmasında (Russel 1980: Fig. 23. 211.2) ve Korucutepe'nin (Winn 1980: Pl. 59.46) EDÇ katlarından tanınmaktadır. Yukarı Fırat Bölgesi'nde yaygın olarak bulunan kırmızımsı kahverengi hamurlu derin kâse formu (Fig. 4: 2), Korucutepe (Winn 1980: Pl. 54.1), Arslantepe III (Manuelli 2012a: 458, Fig. 3.4), Erzurum Pulur (Işıklı ve Erdem 2009: 263, Fig. 14.28) kazılarında EDÇ tabakalarında, Değirmentepe, Kaleköy (Ökse 1988: Abb. 37-38) ve İmikuşağı (Sevin 1983: 399, Res. 7) 
kazılarında ODÇ’nda sık kullanılan bir formdur. Ağız kenarı dışa doğru kalınlaştırılmış, mika, kum ve saman katkılı, pişirmeden kaynaklı siyah alacalı derin kâse (Fig. 4: 3), Korucutepe (Winn 1980: P1. 54. 2), Arslantepe III (Manuelli 2011: 83, Fig. 14; Manuelli 2012a: 458, Fig. 3. 3) ve Büyükardıç’ta (Şenyurt 2005: 455, Fig. 41.5) EDÇ tabakalarından bilinmektedir. Alibey Höyük'de derin kâse formlarını temsil eden "plain ware" (basit seramik) formunda, mat portakal renginde bir başka örnek (Fig. 4: 4), Arslantepe III (Manuelli 2013: 389, Fig. 6.2), Korucutepe (Winn 1980: Pl. 54.1), Pulur (Işıklı ve Erdem 2009: 263, Fig. 14.32), Büyükardıç (Şenyurt 2005: 457, Fig. 42.2) ve Lidar Höyük (Müller 1999: 423, Abb. 13.AA06) kazılarında EDÇ'na tarihlendirilen tabakalarda ele geçen kâse formları ile benzerdir. Hitit etkili bu seramik formu (Fig. 4: 4) Orta Anadolu'da yapılan yüzey araştırmalarında Demir Çağı'na tarihlendirilmiştir (Durbin 1971: 109, Fig. 7.81). Alibey Höyük'te EDÇ'nın tipik seramiği olan "grooved ware" yivli ya da yatay oluk bezemeli grubu temsil eden iki kâse parçası (Fig. 5: 12), elde yapılmış, katkı maddeli, iyi pişirilmemiş örneklerdir. Fig. 5: 1'de yer alan yivli kâsenin en yakın benzerleri, Arslantepe III (Manuelli 2011: 83, Fig. 13), Korucutepe (Winn 1980: Pl. 60.A), İmikuşağ1 (Sevin 1983: 399, Res. 7), Tille Höyük (Blaylock 1999: 276, Fig. 5.1) ve Üçtepe'de (Köroğlu 2002: 472, Res. 9.6) EDÇ’na tarihlendirilmiştir. Fig.5: 2'de yer alan yivli kâse formu, Korucutepe (Winn 1980: Pl. 57.9), Arslantepe III (Manuelli 2012b: 371, Fig. 6.7), Değirmentepe (Esin ve Arsebük 1983: Res. 6.4), Tille Höyük (Blaylock 1999: 276, Fig. 3.9), Giricano (Schachner 2003: 159, Fig. 6.c), Üçtepe'nin (Köroğlu 2002: 472, Res. 9.7) EDÇ tabakalarında ele geçen yivli kâseler ile benzer formdadır. Çizi bezemeli seramik parçası (Fig. 5: 3), Bingöl/Samantepe'de ODÇ’nın başlarına tarihlendirilen çizi bezemeli örnekler (Sevin 1988: 489, Res. 25.1-8, 9) ve Kaleköy ve Şemsiye Tepe'de (Ökse 1988: Abb. 573, 579, 962) ele geçen ODÇ çizi bezemeli parçalar ile benzer özellikler taşımaktadır. Küp gövde parçası olarak değerlendirdiğimiz amorf gövde parçaları (Fig. 5: 4-5), EDÇ'nda Büyükardıç (Şenyurt 2005: 535, Fig. 81), ODÇ’nda Değirmentepe (Ökse 1988: Abb. 1085) ve Bayburt/Kelkit yüzey araştırmasında GDÇ’na tarihlendirilen gövde parçası (Parker 1999: 137, Fig. 2.12) ile benzer bezeme özelliklerine sahiptir. Genellikle gövdesi kabartma şerit bezemeli büyük küplerin kullanımı Doğu Anadolu'da EDÇ'nın başlarından GDÇ sonuna kadar devam etmiştir. Alibey Höyük'te ele geçen iki kulp parçasının üzerinde birden çok (Fig. 5: 6) veya tek (Fig. 5: 7) oluk bezeme bulunmaktadır. Birden fazla oluk bezemeli kulp 
örnekleri EDÇ'nda Korucutepe'den (Winn 1980: Pl. 59.66) bilinmektedir. Tek oluklu kulp örnekleri EDÇ’nda Korucutepe (Winn 1980: 59.67), Hakemi Use ( Tekin 2006: 171, Res. 8.1-2) ve Sos Höyük'te (Sagona 2012: 263, Fig. 2.6) yaygin olarak kullanılmaktadır.

2018 araştırmalarında tespit edilen ve Malatya Ovası üzerinde, Yeşilyurt İlçesi Uğrak Mahallesi/Pınarkolu Mevkii'nde, Tohma Çayı'nın yaklaşı $1 \mathrm{~km}$ güneyinde yer alan, Sivritepe yerleşimi, deniz seviyesinden 712 m yükseklikte, üç tarafı (güney hariç) vadiye bakan yüksekçe bir alan üzerinde bulunmaktadır. Sivritepe yerleşiminde EDÇ'na tarihlediğimiz üzerinde tek oluk bulunan kulp parçası (Fig. 6: 7), Korucutepe'de (Winn 1980: P1. 59.67) EDÇ'nda bilinmektedir. Sivritepe'de, siyah veya kırmızımsı kahverengi paralel bant bezemeli gövde parçaları (Fig. 6: 5-6) EDÇ’nda Arslantepe III (Manuelli 2011: 84, Fig. 15; Manuelli 2012a: 459, Fig. 4.10) ve Büyükardıç'ta (Şenyurt 2005: 541, Fig. 84.3-10) bilinen bir boya bezeme geleneğidir. ODÇ’da da devam eden bu boya bezeme geleneği, Köşkerbaba ve Değirmentepe'de (Ökse 1988: Abb. 602-611;) oldukça yaygındır. Sivritepe'de büyük boy seramik grubuna örnek teşkil edecek, ağız kenarı kalınlaştırılmış, kum katkılı, çok iyi pişirilmiş, çark yapımı kısa boyunlu küp parçası (Fig. 6: 1), EDÇ'nda Büyükardıç'ta (Şenyurt 2005: 557, Fig. 98.1) ve Bingöl/Cankurtaran Tepe'de (Sevin 1987: 27, Fig. 3.4), ODÇ'nda Kaleköy (Ökse 1988: Abb. 338) ve Lidar Höyük’te (Müller 1999: 426, Abb. 16. CB04) kullanılan bir formdur. Sivritepe'de bulunan, boynu içe doğru kavisli, kahverengi astarlı, çark yapımı kadehler (Fig. 6: 2-3), EDÇ’da Büyükardıç'ta (Şenyurt 2005: 495, Fig. 61.4) bilinen bir formdur. Sivritepe kadehleri ile benzer formda olan ve Bingöl/Samantepe'de ele geçen parlak kırmızı astarlı kadeh Urartu seramiği ile ilişkilendirilmiş olup, ODÇ'na tarihlendirilmiştir (Sevin 1988: 488, Res. 24.3). Yine Fig. 6: 2-3 ile benzer formda yapılmış Tokat/Turhal yüzey araştırması sırasında bulunan kırmızı astarlı kadeh, Durbin tarafından Demir Çağı'na tarihlendirilmiştir (Durbin 1971: 109, Fig. 7.61). Urartu etkili bu kadehler muhtemelen Malatya üzerinden Orta Anadolu'ya taşınmış bir formdur. EDÇ ve ODÇ'da Yukarı Fırat Bölgesi'nin yaygın kâse formunu oluşturan ağız kenarı kalınlaştırılmış kâse parçası (Fig. 6: 4), Arslantepe III (Manuelli 2012a: 458, Fig. 3.1), Lidar Höyük (Müller 1999: 434, Abb. 24.AB31), Adıyaman/Hamılıh (Blaylock vd. 1990: 114, Fig. 23.9), Kaleköy ve Değirmentepe'de (Ökse 1988: Abb. 4953) bilinen bir formdur. 
Malatya Ovası üzerinde Yeşilyurt İlçesi, Yeniköy Mahallesi sınırları içerisinde, deniz seviyesinden yaklaşık $711 \mathrm{~m}$ yükseklikte yer alan Kürdonun Bükü Höyük'te ele geçen kabartma şerit bezemeli gövde parçaları (Fig. 7: 1-2), EDÇ'nda Büyükardıç (Şenyurt 2005: 535, Fig. 81), ODÇ’nda Değirmentepe (Ökse 1988: Abb. 1085) ve Bayburt/Kelkit yüzey araştırmasında GDÇ’na tarihlendirilen gövde parçası (Parker 1999: 137, Fig. 2.12) ile benzer bezeme geleneğine sahiptir.

Malatya Ovası'nda Yeşilyurt İlçesi, Yeniköy-2 Mahallesi'nde, deniz seviyesinden $743 \mathrm{~m}$ yükseklikte dalgalı bir morfolojiye sahip, Tohma Çayı'nın batı kıyısında, tepelik bir alan üzerinde yer alan Avşaroğlu Nekropol Alanı'nda bulunan, ağız kenarı içe kavisli kâse (Fig. 7: 3), Değirmentepe'de (Esin ve Arsebük 1983: Res. 6.2; Ökse 1988: Abb. 784) ODÇ’nda bilinen bir formdur. Bu kâselerin, omuzu belirgin bir şekilde keskinleştirilmiş formları, Sos Höyük'te GDÇ'nda bilinmektedir (Parker 1999: 137, Fig. 2.10). Omuzu keskinleştirilmiş örnekler, Altıntepe'de (Emre 1969: Fig. 8) ve İran'ın güneybatısında Pasargad'da (Stronach 1978: Fig. 109.17-18), ODÇ sonlarında ve GDÇ'da yaygın olarak kullanılmıştır.

Yeşilyurt İlçesi'nde ovalık alanda yer alan, deniz seviyesinden $885 \mathrm{~m}$ yükseklikte, Kuşdoğan Mahallesi/Tepecik Mevkii'nde ele geçen, açık gri renkte astarlı, çark yapımı, iyi pişirilmiş sı̆̆ kâse (Fig. 7: 4), EDÇ'nda Erzurum ve Pasinler Ovası'nda (Işıklı ve Erdem 2009: 265, Fig. 16.ZT2), ODÇ’nda Kaleköy'de (Ökse 1988: Abb. 43-45) kullanılan bir formdur. Tepecik'te ele geçen şişkin gövdeli kısa boyunlu, kırmızımsı kahverengi astarlı, çok iyi pişirilmiş, hafif dışa çekik ağızlı kadeh (Fig. 7: 5), Bingöl/Yıldıztepe'de ele geçen ve ODÇ'na tarihlendirilen, Urartu etkili kadeh (Sevin 1988: 498, Res. 41.4) ile aynı formda yapılmıştır. Şişkin gövdeli, kısa boyunlu kadeh formu EDÇ'nda Büyükardıç'ta (Şenyurt 2005: 487, Fig. 57.4) bilinen bir formdur. Tepecik'te bulunan kahverengimsi gri renkte, mineral katkılı, çok iyi pişirilmiş, baskı bezemeli kulp parçası (Fig. 7: 6) ile Karakaya Baraj Bölgesi'nde, Höyükköy'de ODÇ'na tarihlendirilen kulp (Ökse 1988: Abb. 488) form ve bezeme geleneği açısından, oldukça benzerdir.

Yeşilyurt İlçesi'nde, Karahan Köyü’nün yaklaşık 1 km kuzeybatısında yer alan, Örentepe Höyük'te Demir Çağı'nın temsil edildiği 7 parça seramik materyal bulunmuştur. Sultansuyu Vadisi'nin doğu bankında yer alan, deniz seviyesinden yaklaşık $848 \mathrm{~m}$ yükseklikteki höyüğün bat1, kuzeybatı ve 
güneybatı yamacı Sultansuyu Vadisi'ne bakmaktadır. Kırmızımsı kahverengi hamurlu, yavaş dönen çark yapımı, kötü pişirilmiş, ağız kenarı kalınlaştırılmış kâse formu (Fig. 8: 1), ODÇ'nda Kaleköy ve Değirmentepe'de (Ökse 1988: Abb. 132-137), Adiyaman/Hamıllıh'da (Blaylock vd. 1990: 115, Fig. 24.1), Yukarı Mezopotamya'da Dicle Kiyısı'nda Qal'at Šerqat/Assur'da (Hausleiter 2010: Taf. 1.c), Kar-TukultiNinurta (Schmidt 1999: 89, Abb. 7a.17) ve Tille Höyük VIII'de (Blaylock 1999: 278, Fig. 5.29) Yeni Assur tabakalarından bilinmektedir. Assur etkili olduğunu düşündüğümüz ve ODÇ'na tarihlediğimiz başka seramik parçası, kırmızımsı kahverengi astarlı, iyi hamurlu, çark yapımı kadehtir (Fig. 8: 2). Ağız kenarının altı yivli ya da oluklu bu kadeh formları, Kuzeydoğu Suriye'de Tell Rad Shaqrah (Reiche 1999: 247, Fig. 6.c), Aşağ1 Firat Havzası'nda Tell Sheikh Hassan (Schneider 1999: 337, Abb.7.1) ve Yukarı Fırat Bölgesi'nde Köşkerbaba Höyük'ün (Konyar 2004: 426, Lev. XXII.3-4) EDÇ tabakasında ele geçmiştir. Örentepe'de ele geçen, kırmızımsı kahverengi hamurlu çok iyi pişirilmiş, çark yapımı, ağız kenarının altında, ince oluklu çanak formu (Fig. 8: 3) EDÇ ve ODÇ’nda Karakaya Baraj Bölgesi'nde kullanılmıştır. Ağız kenarının altı ince oluklu çanak formu, Arslantepe III'de EDÇ'nda (Manuelli 2013: 388, Fig. 5.11), Değirmentepe'de ODÇ'nda (Ökse 1988: Abb. 879), Lidar Höyük'te ODÇ'nın sonlarında (Müller 1999: 432, Abb. 22.CA15) bilinen bir formdur. Kalın ağız kenarlı, ağız kenarının alt kısmı parmak baskı bezemeli küp formu (Fig. 8: 4), Yukarı Fırat Bölgesi'nde EDÇ’nın sonları ve ODÇ’nda yaygın olan ağız kenarının altı, parmak baskı bezemeli gruba ait bir formdur. Bu formun en yakın paralelini, Değirmentepe'de geniş ağızlı ve düz boyunlu parmak baskı bezemeli (Ökse 1988: Abb. 1110) küp oluşturmaktadır. Örentepe Höyük'te EDÇ'na ait olduğunu düşündüğümüz, çizi bezemeli amorf parça (Fig. 8: 5), bezeme geleneği açısından EDÇ'nda Korucutepe (Winn 1980: Pl. 56. 14), Büyükardıç (Şenyurt 2005: 539, Fig. 83), Sos Höyük'te GBÇ (Sagona 2012: 263, Fig. 2.5) kazılarında ve Ağrı/Kasım Tığg ve Mağaralar Mevkii yüzey araştırmalarında (Marro ve Özfirat 2003: 418, Pl. XV.6,8) ele geçen seramikler üzerindeki bezeme geleneği ile benzerdir. Çizi ve kabartma bezemeli bir başka amorf gövde parçası (Fig. 8: 6), bezeme özellikleri bakımından, Ağrı/Kasım Tı̆̆ı'nda EDÇ'na (Marro ve Özfirat 2003: Pl. XVI.1), Kaleköy'de ODÇ’na (Ökse 1988: Abb. 574) ve Aşağı Fırat Havzası yüzey araştırmasında Horiskale'de Demir Çağı'na (Özdoğan 1977: Pl. 78.15) tarihlendirilen seramiklerin üzerindeki bezeme geleneğini 
yansıtmaktadır. Kabartma şerit bezemeli amorf gövde parçası (Fig. 8: 7), EDÇ'nda Büyükardıç (Şenyurt 2005: 535, Fig. 81), ODÇ'nda Değirmentepe (Ökse 1988: Abb. 1085) ve Bayburt/Kelkit yüzey araştırmasında GDÇ’na tarihlendirilen (Parker 1999: 137, Fig. 2.12) gövde parçası ile benzer bezeme geleneğine sahiptir.

Yeşilyurt İlçesi, Kırkpınar Mahallesi sınırları içerisinde 2017 yüzey araştırmaları sırasında tespit edilen, Tohma Çayı'nın güney bankında, doğal tepelik bir alan üzerinde yer alan Sarılık Tepe'nin (Dönmez 2019: 49), kuzey yamacı eteklerinde, Tohma Çayı suyunun çekilmesi ile açığa çıkan alanda ele geçen büyük bir küpe ait, kabartma şerit bezemeli gövde parçası (Fig. 8: 8), EDÇ’nda Korucutepe (Winn 1980: Pl. 57. 10) ve Büyükardıç (Şenyurt 2005: 535, Fig. 81), ODÇ'nda Değirmentepe'de (Ökse 1988: Abb. 1085) kullanılan büyük küpler üzerindeki kabartma şerit bezeme geleneğini yansitmaktadir.

Malatya Ovası ve yakın çevresi üzerinde yer alan yerleşimlerde, EDÇ’nı temsil eden seramikler yanında, Assur ve Urartu etkisini gösteren ODÇ seramikleri ile GDÇ'ında Akhamenid etkili seramik parçaları, bölgenin yoğun bir geçiş özelliğine sahip olduğunu göstermesi bakımından önemlidir.

Malatya Dağları üzerinde yürütülen arkeolojik yüzey araştırması sırasında, Beypınar Tepe, Kilise Tepe, Seyituşağı Kale Arkeolojik Alanı, Meydan Kalesi, Cihan Kalesi, Aşağıköy Kalebaşı ve Ziyaret Tepe olmak üzere 7 merkezde Demir Çağı'na ait seramik materyal toplanmıştır (Fig. 15). Bulunan seramik materyal, Malatya Ovası ile yayla kültürleri açısından oldukça önemli, kuzey-güney yönünde çeşitli geçişler sunan Malatya Dağları üzerindeki merkezlerin kültürel ilişkilerinin ortaya konması açısından veriler sunmaktadır.

Malatya Dağları üzerinde, Battalgazi İlçesi, Söğüt Mahallesi Büyük Karadere ve Küçük Karadere Mevkiileri sınırları arasında kalan Beypınar Mezrası'nda yer alan, deniz seviyesinden 1790 m yükseklikte, doğal tepelik bir alan üzerine kurulmuş Beypınar Tepe yerleşimi, Kubbe Dağı Çad Mevkii maden işlik alanın yaklaşık $11 \mathrm{~km}$, Puluşağı Maden Deresi maden işlik alanın ise $12.5 \mathrm{~km}$ kuzeybatısında yer almaktadır (Dönmez 2019: 53). Tarım yapılacak alanlar oldukça sınırlı olduğundan dolayı, tipik bir yayla yerleşimi olan Beypınar Mezrası'nda, küçükbaş hayvancılık başlıca geçim kaynağını oluşturmaktadır. Beypınar Tepe'nin kuzey ve kuzeydoğu yamacı sarp kayalık bir alan olup, vadiye açılmaktadır. Yerleşimin kuzey yamacında, 
doğal sarp kayalık alanla birleştirilmiş taş duvar kalıntısı kısmen korunmuştur. Savunma amaçlı kullanıldığını düşündügümüz bu yerleşim, Geç Bronz Çağ II'de ve EDÇ’nda Nahçıvan ve Doğu Anadolu Bölgesi’nde kalelere uygulanan, sarp ve dik alanların savunma duvarları ile birleştirilmesi uygulamasının tipik bir örneğini yansıtmaktadır (Belli ve Konyar 2003: 31). Beypınar Tepe'de ele geçen kahverengimsi gri astarlı, mineral katkılı, kötü pişirilmiş, el yapımı, ağız kenarı kalınlaştırılmış küp parçasının formu (Fig. 9: 1), EDÇ'nda Büyükardıç (Şenyurt 2005: 509, Fig. 68.5), Korucutepe (Winn 1980: Pl. 59.50) ve Lidar Höyük'ten (Müller 1999: 419, Abb. 9.CB02) bilinmektedir. Beypınar Tepe'de ele geçen parmak baskı bezemeli, muhtemelen bir küpe ait olduğunu düşündügümüz gövde parçaları (Fig. 9: 2-3), EDÇ’nın sonları ODÇ’nda, Malatya Ovası'nda, büyük küplerde sıklıkla kullanılan parmak baskı bezeme geleneğini yansıtmaktadır (Ökse 1988: Abb. 1097). Beypınar Tepe'de şerit kabartma bezemeli gövde parçası (Fig. 9: 4), daha önceden belirttiğimiz gibi EDÇ ve ODÇ’nda sıklıkla kullanılan şerit kabartmalı bezeme geleneğini yansıtan tipik bir örnektir. EDÇ'na ait olduğunu düşündüğümüz bir başka baskı bezemeli amorf parça (Fig. 9: 5), Kuzeydoğu Anadolu'da, Sos Höyük (Sagona 2012: 267, Fig. 6.56) ve Büyükardıç’ta (Şenyurt 2005: 525, Fig. 76.7-9) bulunan baskı bezemeli amorf parçalar üzerindeki bezeme geleneğine sahiptir.

Malatya Dağları üzerinde, Yeşilyurt İlçesi, Cumhuriyet-Örnekköy Mahallesi sınırları içerisinde deniz seviyesinden 1400 m yükseklikte, doğal tepelik bir alan üzerine kurulmuş, Malatya Ovası'nın güneydoğusunda, ovaya hâkim bir konumda yer alan Kilise Tepe'nin yakın çevresinde yayla kültürüne dayalı, küçükbaş hayvancılık yapılmaktadır. Kilise Tepe'de ele geçen oluk bezemeli kulp parçası (Fig. 9: 6), EDÇ'nda Korucutepe (Winn 1980: Pl. 59. 67) ve ODÇ’nda Değirmentepe'de (Ökse 1988: Abb. 1061) bilinen bir formdur. Kilise Tepe'de bezemeli amorf parça (Fig. 9: 7) üzerindeki bezeme geleneği EDÇ'nda Korucutepe (Winn 1980: Pl. 56. 6, 9, 14), Sos Höyük (Sagona 2012: 266, Fig. 5.5), Van/Ernis-Evditepe Nekropolü (Konyar 2004: 510, Lev. CV.7), ODÇ'nda Değirmentepe'den bilinen bir bezeme geleneğidir (Ökse 1988: Abb. 691). Şerit kabartma bezemeli amorf parça (Fig. 9: 8) EDÇ’ndan GDÇ’nın sonlarına kadar kullanılan bir bezeme geleneğini yansıtmaktadır.

Malatya Dağları üzerinde, Yeşilyurt İlçesi, Seyituşağı Mahallesi sınırları içerisinde, modern köy yerleşiminin $250 \mathrm{~m}$ güneyinde, deniz 
seviyesinden 1440 m yükseklikte, yaklaşık 245 x 237 m ebatlarında bir alana yayılan, kuzey ve kuzeydoğu yamacı sarp kayalıklardan oluşan, sarp kayalık alanın bazı noktalarında savunma duvarları inşa edilmiş, Seyituşağı Kale Arkeolojik Alanı'nda, Demir Çağı'na tarihlendirilen seramik parçaları bulunmuştur. EDÇ’nda Doğu Anadolu Bölgesi'nde yaygın kullanılan sarp kayalık alanların savunma duvarları ile birleştirilip, kullanılması geleneği bu yerleşimde de göze çarpmaktadır. Tarihleme konusunda şüpheye düştüğümüz, yerleşimin yüzeyinde bulunan ve GBÇ'nın sonlarında Orta Anadolu'da yaygın bir form olan "plain ware" tipi sığ kâse (Fig. 10: 1), Sos Höyük'te EDÇ'na tarihlendirilen kâse ile benzer formda yapılmıştır (Güneri 2002: 27, Pl. 2.10). Gövdesi hafif dışa doğru kavisli, yoğun mineral katkı11, çark yapımı kâse'nin (Fig. 10: 2) en yakın paraleli GDÇ’nda Erzrurum/Tasmasor' da (Şenyurt vd. 2011: 217, Fig. 3.32) bulunmuştur. Bu form Tokat-Sivas yüzey araştırmalarında "plain ware" grubu içerisinde değerlendirilen ve Demir Çă̆g'na tarihlendirilen kâse formu ile de benzerdir (Durbin 1971: 109, Fig. 7.89). Kale Arkeolojik Alanı'nda Assur etkisini yansıtan, ağız kenarının altı yivli kadeh formu (Fig. 10: 3), Kuzeydoğu Suriye'de Tell Rad Shaqrah (Reiche 1999: 247, Fig. 6.c), Aşağ1 Firat üzerinde Tell Sheikh Hassan (Schneider 1999: 337, Abb.7.1) ve Yukarı Firat Bölgesi'nde Köşkerbaba Höyük'ün EDÇ tabakasında (Konyar 2004: 426, Lev. XXII.3-4) ele geçmiştir. Güney etkili olduğunu düşündüğümüz, ağız kenarı dışa doğru kalınlaştırılmış, düz uzun boyunlu kavanoz formu (Fig. 10: 4), EDÇ’nda Lidar Höyük’ten (Müller 1999: 413, Abb.3.AB03) ve Aşağ 1 Frrat Havzası'nda Tell Sheikh Hassan'dan (Scneider 1999: 344, Abb. 14.12) bilinmektedir.

Yeşilyurt İlçesi, Meydan Kalesi, Malatya Dağları üzerinde, Görgü Mahallesi, Kaçak Mevkii sınırları içerisinde, yöre halkı tarafından Meydan (Mendol) Yaylası olarak adlandırılan alanın kuzeybatısında, doğal tepelik ve kayaç bir alan üzerine kurulmuş, muhtemelen savunma amaçlı kullanılmış bir yerleşimdir. Deniz seviyesinden 1850 m yükseklikte yer alan yerleşimin kısmen kuzeydoğu ve doğu yamacı sarp kayalık alan üzerine oturtularak doğal bir savunma duvarı oluşturulmuştur. Yerleşimin doğu, güneydoğu ve güney yamaçları taş duvarla örlmüştür. Kale'nin tepe kısmında savunma duvarının kalıntıları izlenmektedir. Doğu Anadolu Bölgesi Demir Çağı kalelerinin genel özelliklerini taşıyan bu yerleşimin yaklaşık $6 \mathrm{~km}$ güneybatısında yer alan Tepeyurt ve İbicek Mevkii demir madeni kaynakları ve işlik alanı bulunmaktadır (Dönmez 2019: 55). Yüzeyde toplanan maden 
cürufları ve Meydan Kalesi'nin yaklaşık $1 \mathrm{~km}$ güneydoğusunda yer alan demir madeni işlik alanı bu yerleşimin maden üretimi açısından önemini ortaya koymaktadır. Yerleşimin çevresinde, özellik Meydan Yaylası'nda günümüzde küçükbaş hayvancılığın yapıldığı yayla kültürleri kısmen devam etmektedir. Meydan Kalesi'nde, EDÇ ve ODÇ seramik kültürünü yansitan seramik parçaları ele geçmiştir. Assur etkili, "carinated bowl" tipi, omuzları keskinleştirmiş, ağız kenarı kalınlaştırılmış kâse formu (Fig. 10: 5), EDÇ'nda Arslantepe III'de (Manuelli 2011: 83, Fig. 14), Habur Bölgesi'nde Tell Barri'nin Orta Assur Dönemi tabakasinda (D'Agostino 2009: 38, Fig. 8.29, Type 256), ODÇ'nda Değirmentepe'de (Ökse 1988: Abb. 245) ve Lidar Höyük'te (Müller 1999: 434, Abb. 24.AB33) kullanılan bir formdur. Yuvarlak yumru bezemeli gövde parçası (Fig. 10: 6) üzerindeki yumru bezeme geleneği, EDÇ'nda Korucutepe (Winn 1980: Pl. 52.2), Hakemi Use (Tekin 2006: 170, Res. 7.1), Büyükardıç (Şenyurt 2005: 537. Fig. 82) ve Norşuntepe'de (Konyar 2004: 407, Lev. V.10) yaygin olarak kullanılmaktadır. Kötü pişirilmiş, kaba yapılmış, taşçılıl, portakal renginde, tarihleme konusunda şüpheye düştüğümüz bezemeli, amorf seramik parçası (Fig. 10: 7) üzerindeki bitkisel bezeme stili, EDÇ'nda Korucutepe'de (Winn 1980: Pl. 56.14), Van Müzesi'ne Patnos ve çevresinden satın alma yoluyla gelen seramiklerde (Konyar 2004: 523, Lev. CXVIII.2-3) ve Ağr1/Gre Herşe yüzey araştırmasında saptanan seramik (Marro ve Özfırat 2003: 416, Pl. XIII.3) üzerindeki bitkisel bezemeler ile benzerdir. EDÇ’nda bu bitkisel bezeme stilinin sadece seramiklerde değil, silindir mühür üzerinde de kullanıldığını Korucutepe'nin EDÇ tabakasında ele geçen silindir mühürden bilmekteyiz (Winn 1988: Pl. 63.H). Meydan Kalesi'nde bulunan, ağız kenarı kalınlaştırılmış, oldukça kaba yapılmış, ağız kenarı ve boynu üç sıra parmak baskı bezemeli küp (Fig. 10: 8), Köşkerbaba kazılarında bulunan ve ODÇ'na tarihlendirilen küp ile gerek form gerekse bezeme geleneği açısından paraleldir (Ökse 1988: Abb. 1121). Meydan Kalesi'nde ODÇ'na tarihlediğimiz bir başka parmak baskı bezemeli küp parçasının (Fig. 10: 9) Değirmentepe'de (Esin ve Arsebük 1983: Res. 6.12-13) ve Köşkerbaba'da (Ökse 1988: Abb. 1108) bulunan en yakın formu, bezeme geleneği açısından da paralellik gösterir.

Yeşilyurt İlçesi sınırları içerisinde, Atalar Mahallesi Fadıloymağ Mevkii'nde, Malatya ile güney bağlantılarını oluşturan geçiş noktası üzerinde yer alan kuzeydoğu-güneybatı doğrultulu, deniz seviyesinden 1837 m yükseklikte, doğal tepelik bir alan üzerine kurulmuş, etrafı doğal kayalık 
alan ve surlarla örülmüş Cihan Kalesi, savunma amaçlı kullanılmış olabilecek bir yerleşimdir. Bölgenin yüksek rakımı ve tarım arazilerinin oldukça sınırlı olması nedeniyle, bölgede geçim kaynağını hayvancılık oluşturmaktadır. Meydan Kalesi'nin yaklaşık $2.5 \mathrm{~km}$ doğusunda yer alan bu yerleşimde, Demir Çağı'nı temsil eden 10 adet seramik parçası tespit edilmiştir. Yerleşim, Meydan Kalesi'nde olduğu gibi maden kaynaklarına yakın bir konumda bulunmaktadır. Cihan Kalesi'nin yaklaşık $7 \mathrm{~km}$ doğusunda Kuyuluk maden işlik alanı ve $8 \mathrm{~km}$ güneybatısında İbicek ve Tepeyurt demir madeni ocakları ve işlik alanı bulunmaktadır. Cihan Kalesi, yayla kültürlerinin temsil edildiği bir bölge üzerinde hayvancıllk ve madenciliğe dayalı bir yerleşimdir. Çark yapımı, ince kum ve saman katkılı hafif omuzlu kadeh formları (Fig. 11: 1-2), ODÇ'nda Kaleköy Höyük'te (Ökse 1988: Abb. Abb. 25) bilinen bir formdur. Kalınlaştırılmış ağız kenarlı kâse formu (Fig. 11: 3), EDÇ’nda Arslantepe III (Manuelli 2012a: 458, Fig. 3.1) ve Lidar Höyük (Müller 1999: 420, Abb. 10.AA02), ODÇ’nda Değirmentepe'de (Ökse 1988: Abb. 53) yaygın olarak kullanılan kâse formunu oluşturmaktadır. Adıyaman/Hamılıh yüzey araştırması sırasında bulunan kalınlaştırılmış ağız kenarlı bu formun en yakın paraleli Yeni Hitit seramik grubu içerisinde değerlendirilmiştir (Blaylock vd. 1990: 115, Fig. 24.16). Kırmızımsı kahverengi astarlı, açkılı, çark yapımı, kötü pişirilmiş, gövdesi paralel yivli kâse formu (Fig. 11: 4), yivli seramiğin bölgesel bir çeşidini temsil etmekte olup, güneyde EDÇ'nda Yukarı Dicle Bölgesi'nde Eliaçı/Köpekli Höyük'te ele geçen kâse formu ile benzerdir. ODÇ tabakasında paralel yiv bezemeli bu kâse formunun devam ettiğini Lidar Höyük'te ODÇ’na tarihlendirilen benzer bir kâse formundan bilmekteyiz (Müller 1999: 429, Abb. 19. AB25). Ağız kenarı kalınlaştırılmış, boynu içe doğru kavisli, kırmızımsı kahverengi astarlı kötü pişirilmiş, el yapımı küp (Fig. 11: 5), EDÇ’na ait, Büyükardıç (Şenyurt 2005: 495, Fig. 61.6) ve Elazı̆g/Haroğlu'ndan (Sevin 1987: Res. 43.7) ele geçen küplerle benzer form özelliklerine sahiptir. Açık kahverengi astarlı, taşçılı, yavaş dönen çark yapımı, iyi pişirilmiş, ağız kenarından kulplu kavanoz (Fig. 11: 6), form özellikleri bakımından, EDÇ’nda Korucutepe'de (Winn 1980: Pl. 53.10; Konyar 2004: 411, Lev. IX.2) ve Van/Ernis-Evditepe Nekropolü'nde (Konyar 2004: 504, Lev. XCIX) bulunan kavanozlarla benzerdir. Kavanozun kulpu ve boynu üzerindeki çizi ve baskı bezeme geleneği, ODÇ’nda Kaleköy'de (Ökse 1988: Abb. 573, 577) ele geçen seramik parçaları üzerindeki bezemelerden tanınmaktadır. Cihan Kalesi'nde ele geçen kulp 
parçalarından üç örnek (Fig. 11: 7-9) üzerinde, kulpların gövde ile birleşme noktasindan itibaren kısa oluk bezemeler mevcuttur. Oluk bezemeli kulp geleneği EDÇ’nda bilinmesine rağmen ODÇ’nda da devam etmiştir. EDÇ’nda tek oluk bezemeli kulp örneği Korucutepe'den bilinmektedir (Winn 1988: Pl. 59.67). Çoklu oluk bezemeli kulp geleneği, Değirmentepe'de ODÇ'nda (Ökse 1988: Abb. 1061) bilinen bir bezeme türüdür. Cihan Kalesi'nde ele geçen kırmızımsı kahverengi hamurlu, iyi pişirilmiş, el yapımı, parmak bask1 bezemeli gövde parçası (Fig. 11: 10) üzerindeki baskı bezeme, Yukarı Frrat Bölgesi'nde, Karakaya Baraj Bölgesi'ndeki höyüklerde, ODÇ’na tarihlendirilen küplerin ağız, boyun ve gövdesi üzerinde yaygın olarak kullanılmaktadır (Ökse 1988: Abb: 1097, 1117, 1121).

Yeşilyurt İlçesi, Aşağıköy Mahallesi Kırkşar Mevkii'nde, deniz seviyesinden yaklaşık $1450 \mathrm{~m}$ yükseklikte, Çat Barajı'nın yaklaşık $1.7 \mathrm{~km}$ kuzeydoğusunda yer alan Kalebaşı, doğal tepelik ve kayaç bir alan üzerine kurulmuştur. Yaklaşık 250 x $90 \mathrm{~m}$ ebatlarında bir alana yayılan bu yerleşimin kuzeybatı ve batı yamacı tamamen sarp kayalık alandan oluşmaktadır. Kalebaşı yerleşimi, doğal savunma oluşturan sarp kayalık alandan itibaren, kuzey ve güney yamacı taş duvarlarla örülmüştür. 2017 yüzey araştırması sırasında tespit edilen ve demir madeni işleme alanı olarak kullanıldığını düşündüğümüz Salkonak Mağarası I'in yaklaşı $4.6 \mathrm{~km}$ kuzeybatısında yer alan bu yerleşim, muhtemelen savunma amaçlı kullanılmış olup, Malatya Dağları ile güney bağlantısını sağlayan geçit üzerinde yer almaktadır (Dönmez 2019: 53). Kalebaşı'nda ele geçen ağız kenarı kalınlaştırılmış, dışa çekik ağızlı, derin kâse (Fig. 12: 1) formu, ODÇ’nda Assur etkili merkezlerde ele geçmiştir. Qal-at Šerqat/Assur'da, Yeni Assur Dönemi'ne tarihlendirilen kâselerle (Hausleiter 2010: Taf. 64. ST1.1-ST1.2) benzer form özelliklerine sahiptir. Ağız kenarı kalınlaştırılmış bu kâse formu, Habur Bölgesi'nde Tell Barri'de, Orta Assur Dönemi tabakalarında (D’Agostino 2009: 37, Fig. 7.33A, Type 210B), Tille Höyük'te (French 1986: 212, Res. 5. 1), Değirmentepe'de (Ökse 1988: Abb. 853) ve Lidar Höyük'te (Müller 1999: 434, Abb. 24.AB35) ODÇ’nda kullanılan bir formdur. Ağız kenarının altı hafif içe kavisli, derin kâse formu (Fig. 12: 2), Tille Höyük'te (French 1986: 212, Res. 5.5) ve Değirmentepe'de (Ökse 1988: Abb. 17) ODÇ’na, Lidar Höyük'te (Müller 1999: 420, Abb. 10.AA05) EDÇ'nın sonlarına tarihlendirilen kâselerle benzer formdadır. Kahverengi hamurlu, taşçıklı, dışa çekik ağız kenarlı kâse 
(Fig. 12: 3), form özellikleri bakımından Adıyaman/Hamılıh yüzey araştırmasında bulunan ve ODÇ'na tarihlendirilen kâse formu ile benzerdir (Blaylock vd. 1990: 116, Fig. 25.14). Kalebaşı'nda ele geçen bezemeli gövde parçası (Fig. 12: 4) üzerindeki bezeme geleneği, Aşağ1 Fırat Havzası yüzey araştırması kapsamında, Horiskale'de bulunan gövde parçası üzerindeki dalgalı yivli bezemeyle benzerdir (Özdoğan 1977: Pl. 78. 15). Dalgalı yivli bezeme geleneği, EDÇ’nda Kuzeydoğu Anadolu'da bilinen bir bezeme türüdür. Ağr1/Kasımtığı ve Mağaralar Mevkii'nde ele geçen gövde parçaları üzerindeki dalgalı yiv bezemeli seramik parçaları EDÇ’na tarihlendirilmiştir (Marro ve Özfirat 2003: 419, Pl. XVI.1-4). Yukarı Fırat Havzası'nda, Karakaya Baraj Bölgesi'nde yer alan Kaleköy Höyük'te ODÇ'nda, dalgalı yivli bezeme geleneğinin devam ettiğini görmekteyiz (Ökse 1988: Abb. 573-576).

Yeşilyurt İlçesi, Üçgöze Köyü’nün 200 m güneyinde, Malatya Dağları üzerinde, güney ve güneybatı yamacı hariç, sarp alandan oluşan Ziyaret Tepe, yayla kültürleri tarafindan kutsal kabul edilen ve halen sıklikla ziyaret edilen doğal tepelik bir alandır. Deniz seviyesinden 1866 m yükseklikte yer alan Ziyaret Tepe'nin çevresi, yarı göçebeler tarafından hayvan otlatmak amacıyla kullanılmaktadır. Ziyaret Tepe'de etrafa dağılmış halde bulunan seramik parçaları içerisinden birisini Demir Çă̆ı'na tarihlemeyi uygun bulduk. Avşaroğlu Nekropol Alanı'nda bulunan, ağız kenarı içe kavisli kâse (Fig. 7: 3) formuyla oldukça benzer olan, kırmızımsı gri renkte, mineral ve saman katkılı, taşçıklı, kötü pişirilmiş, çark yapımı kâse (Fig. 12: 5), Değirmentepe'de (Ökse 1988: Abb. 784) ODÇ'nda bilinen bir formdur. Daha önceden de belirttiğimiz gibi bu kâselerin omuzu belirgin bir şekilde keskinleştirilmiş formları, Sos Höyük'te GDÇ'nda bilinmektedir (Parker 1999: 137, Fig. 2.10). Omuzu keskinleştirilmiş örnekler, Altıntepe'de (Emre 1969: Fig. 8) ve İran'in güneybatısında Pasargad'da (Stronach 1978: Fig. 109.17-18), ODÇ sonlarında ve GDÇ'da yaygın olarak kullanılmıştır.

\section{Sonuç}

2018 yüzey araştırması yapılan, Malatya Ovası ve Malatya Dağları'nı kapsayan sahada, GBÇ'nin sonlarından itibaren bölgenin etkin bir geçiş noktası özelliğini taşıdığını gösteren Demir Çağı buluntuları saptanmıştır. Araştırma yapılan sahada, Erken Demir Çağı'nda, Orta Anadolu, Kuzeydoğu Anadolu ve Orta Assur Dönemi seramiğinin, yerel seramik örnekleriyle birlikte kullanıldığını görmekteyiz. Malatya Dağları üzerinde, özelikle EDÇ 
ve ODÇ’nda, bölgeyi kullanan göçebe grupların, politik bir yapılanma içerisine girdiğini gösteren kale yapıları, Demir Çağı'nda, Doğu Anadolu Bölgesi'nde sıklıkla rastlanan, doğal savunma oluşturan sarp kayalık alanların, taş duvar örgüleriyle desteklenerek oluşturulan savunma yapılarının özelliklerini taşımaktadır. EDÇ’nda ve özellikle ODÇ’nda yoğun olarak kullanıldığını düşündüğümüz bu savunma yapılarının olduğu alanlarda, Yukarı ve Aşağı Fırat Havzası ve Yukarı Dicle Bölgesi ile yoğun etkileşimi gösteren seramik parçaları bulunmaktadır. Demir Çağı'nda yoğun olarak kullanılan Malatya Ovası ve Malatya Dağları arasındaki yerleşimlerde, seramik kültürü oldukça benzerdir. Malatya Dağları üzerinde yer alan demir madeni işlik alanları ve hayvancılık için uygun yaylaları, Demir Çağı'nda göçebe topluluklar tarafından yoğun kullanılmış olup, Malatya Ovası'ndaki yerleşimlerle etkileşim, göçebe ve yerleşikler arasındaki ticaretin de bir göstergesi kabul edilebilir. Malatya Dağları üzerindeki savunma yapılarının bulunduğu Demir Çağı merkezleri, bölgesel geçişin kontrol edilebileceği stratejik noktalarda ve aynı zamanda maden kaynaklarına ve hayvancıllğa uygun alanlarda kurulmuştur. Bu savunma yapıları, Malatya Dağları üzerindeki göçebe topluluklarla Malatya Ovası üzerindeki yerleşik topluluklar arasındaki ticari etkileşimin, en azından maden ticaretinin, rastgele değil, düzenli politik bir organizasyonla gerçekleştirilmiş olabileceğini düşündürmektedir. Zira EDÇ'nda büyük oranda çöken, saray organizasyonuna dayal1, uzak mesafe maden ticareti, özellikle kalay ticareti nedeniyle, bronz yapımı için kalaya ulaşamayan topluluklar, bölgenin demir madeni kaynaklarını yoğun olarak tüketmiştir. Malatya Dağları üzerinde yer alan ve çoğunlukla savunma duvarlarına sahip yerleşimlerde ele geçen kırmızımsı kahverengi astarlı, kaba yapılmış, parmak baskı bezemeli mal grubu, ODÇ'nda Malatya Ovası üzerindeki höyüklerde ele geçen seramik buluntularla bezeme ve yapım tekniği bakımından paralellik göstermektedir. Malatya Dağları üzerinde, baskı ve çizi bezemeli seramik parçalarının bulunduğu Demir Çağı merkezleri, Kuzeydoğu Anadolu'da EDÇ’nda yaygın olan bezeme geleneğinin güneye aktarımında, geçiş bölgesi özelliği gösterir. "Carinated bowl" olarak adlandırılan Assur tipi seramik örnekleri, Assur-Arami etkileşiminin bir sonucu olarak, EDÇ ve ODÇ’nda Malatya Dağları'nda, Demir Çağı merkezlerinde ve ovalık alanda kullanılan bir formu oluşturmaktadır. Tepecik Mevkii'nde bulunan ve ODÇ'na tarihlendirilen kırmızımsı kahverengi astarlı, çok iyi pişirilmiş, çark yapımı kadeh, Malatya Ovası 
üzerinde, Urartu etkisini yansıtan önemli bir örnektir. EDÇ’nda Malatya Ovası üzerinde yaygın olarak kullanılan oluklu ya da yiv bezemeli seramik formları, Malatya Dağları üzerinde yer alan ve yüzey araştırmalarımız sırasında tespit edilen Demir Çağı merkezlerinde neredeyse hiç yoktur. Cihan Kalesi'nde bulunan yivli kâse, Malatya Ovası'nda ve Karakaya Baraj Bölgesi'nde bulunan yivli kâselerle form özellikleri bakımından oldukça farklıdır. Yukarı Dicle Bölgesi etkisini taşıyan bu form, güneydeki göçebe gruplar tarafından Malatya Dağları üzerindeki Cihan Kalesi'ne taşınmış olmalıdır. Malatya Dağları üzerinde, savunma amaçlı kullanılan merkezlerde, EDÇ’nda Kuzeydoğu Anadolu'da sıklıkla kullanılan bezeme geleneğini görmek mümkündür. Malatya Dağları üzerindeki Demir Çağı merkezlerinde, ODÇ'nda Karakaya Baraj Bölgesi'nin yerel seramiği ve Assur etkili Yukarı Dicle Bölgesi'nin seramik kültürü yoğun olarak hissedilmektedir. Yivli ya da oluk bezemeli örnekler hariç, bölgenin bazı Demir Çağı seramik formlarında dönemsel geçiş, özellikle EDÇ ve ODÇ’nda yoğun olarak hissedildiğinden, yüzey araştırmasında saptanan bazı buluntuların kesin olarak Demir Çağı'nın hangi dönemine tarihlendirilmesi gerektiği, çalışmanın en büyük problemini oluşturmaktadır. Malatya Bölgesi, sıklıkla belirttiğimiz gibi bir geçiş bölgesi özelliğinden dolayı, yerel formların ya da kuzey-güney etkili formların, başka bölgelere taşınması ve daha sonradan göçebe topluluklar tarafından, kısmen bazı farklılıklarla tekrar bu bölgeye getirilmesi söz konusu olmalıdır. Örneğin Malatya Ovası'ndaki yerleşimlerde ele geçen yivli seramiklerin farklı bir formunun Cihan Kalesi'nde bulunması bu duruma örnek teşkil edebilir.

\section{Figürler}

Fig. 1: Alibey Höyük

1- Küp, ağız kenarı, Ç: $44 \mathrm{~cm}, \mathrm{Y}: 10.6 \mathrm{~cm}, 10 \mathrm{YR}$ 8/4 açık sarımsı portakal renginde astarlı, kalın cidarlı, kaba kum, mika ve saman katkılı, kötü pişirilmiş, açkılı, el yapımı, ağız kenarının altında parmak baskı bezemeli.

2- Küp, amorf gövde parçası, 10 YR 8/1 aç1k gri renkte astarlı, kaba kum ve saman katk1l1, açk1lı, parmak baskı bezemeli, kötü pişirilmiş, kalın cidarlı, el yapımı.

Fig. 2: Alibey Höyük

1- Çanak, ağız kenarı, Ç: $44 \mathrm{~cm}, \mathrm{Y}: 5.1 \mathrm{~cm}, 10 \mathrm{YR}$ 8/3 açık sarımsı portakal, hamur renginde astarlı, kaba kum, mika ve saman katkılı, kalın cidarlı, iyi pişirilmiş, el yapımı.

2- Kâse, ağız kenarı, Ç: $14 \mathrm{~cm}, \mathrm{Y}: 2.1 \mathrm{~cm}, 10 \mathrm{YR}$ 8/1 açık gri renkte astarlı, ince kum, mineral ve mika katkılı, kötü pişirilmiş, ince cidarlı, el yapımı. 
3- Kâse, ağız kenarı, Ç: $22 \mathrm{~cm}, \mathrm{Y}: 4.5 \mathrm{~cm}, 7.5$ YR 8/2 açık renkte astarlı, kum, şamot ve ince saman katkıl1, ince cidarlı, açk1lı, kötü pişirilmiş, çark yapımı..

4- Çömlek, ağız kenarı, Ç: $30 \mathrm{~cm}, \mathrm{Y}: 7.1 \mathrm{~cm}, 7.5$ YR 8/3 açık sarımsı portakal, hamur renginde astarlı, kaba kum ve saman katkılı, kötü açkılanmış, yavaş dönen çark yapımı.

\section{Fig. 3: Alibey Höyük}

1- Kadeh, ağız kenarı, Ç: $14 \mathrm{~cm}, \mathrm{Y}: 3.3 \mathrm{~cm}, 2.5 \mathrm{YR}$ 8/1 kırmızımsı gri renkte hamurlu, ince kum ve yoğun mika katkılı, ince cidarlı, iyi pişirilmiş, açkılı, çark yapımı.

2- Kadeh, ağız kenarı, Ç: $15 \mathrm{~cm}, \mathrm{Y}: 2.9 \mathrm{~cm}, 7.5 \mathrm{YR} 7 / 4$ mat portakal renginde hamurlu, dış yüzeyi pişirmeden kaynaklı siyah alacalı, orta derecede pişirilmiş, kaba kum ve saman katkıl1, yavaş dönen çarkta yapılmış.

3- Testi, ağız kenarı, Ç: $6 \mathrm{~cm}, \mathrm{Y}: 5.7 \mathrm{~cm}, 10 \mathrm{YR}$ 8/2 açık gri renkte astarlı, yoğun kum ve mineral katkılı, iyi pişirilmiş, çark yapımı.

4- Kavanoz, ağız kenarı, Ç: $24 \mathrm{~cm}, \mathrm{Y}: 3.5 \mathrm{~cm}, 7.5$ YR 8/3 açık sarımsı portakal renginde, yoğun mineral, mika, ince kum ve ince kıyılmış saman katkılı, orta derecede pişirilmiş, ağız kenarının iç kısmı muhtemelen kapak konması için oluklu yapılmış, çark yapımı.

\section{Fig. 4: Alibey Höyük}

1- Kâse, ağız kenarı, Ç: 15 cm. Y: $4.1 \mathrm{~cm}, 7.5$ YR 5/3 grimsi kahverengi hamurlu, kum, şamot ve saman katkılı, kötü pişirmeden kaynaklı dış yüzeyi siyah, el yapımı.

2- Kâse, ağız kenarı, Ç: $20 \mathrm{~cm}$, Y: $5.3 \mathrm{~cm}, 5$ YR 5/4 mat kırmızımsı kahverengi hamurlu, yoğun mineral, mika ve saman katkılı, dış yüzeyi pişirmeden kaynaklı siyah alacalı, ince cidarlı, çark yapımı.

3- Kâse, ağız kenarı, Ç: $20 \mathrm{~cm}, \mathrm{Y}: 7.5 \mathrm{~cm}, 7.5$ YR 8/3 açık sarımsı portakal renginde hamurlu, mika, kum ve saman katkılı, dış yüzeyi pişirmeden kaynaklı siyah alacalı, açkı1ı, yavaş dönen çark yapımı.

4- Kâse, ağız kenarı, Ç: $16 \mathrm{~cm}, \mathrm{Y}: 4.5 \mathrm{~cm}, 5$ YR 8/4 mat portakal renginde astarlı, iyi pişirilmiş, kum, şamot ve saman katkılı, iyi açkılanmış, yavaş dönen çark yapımı.

5- Kâse, ağız kenarı, Ç: $20 \mathrm{~cm}, \mathrm{Y}: 5.3 \mathrm{~cm}, 7.5$ YR 8/2 açık gri renkte astarlı, kum ve saman katk1lı, açkılı, iyi pişirilmiş, çark yapımı.

\section{Fig. 5: Alibey Höyük}

1- Kâse, ağız kenarı, Ç: $16 \mathrm{~cm}, \mathrm{Y}: 8 \mathrm{~cm}, 7.5 \mathrm{YR}$ 7/4 mat portakal renginde, kum, şamot ve saman katkılı, kötü pișirilmiş, yivli ya da oluk bezemeli, kötü açkılanmış, el yapımı.

2- Kâse, ağız kenarı, Ç: $14 \mathrm{~cm}$, Y: $4.8 \mathrm{~cm}, 7.5$ YR 8/4 açık sarımsı portakal renginde, kum, kireç ve mika katkıl1, açk111, orta derecede pişirilmiş, el yapımı.

3- Amorf gövde parçası, 7.5 YR 7/4 kırmızımsı kahverengi hamurlu, kum ve şamot katkılı, iyi pişirilmiş, çizi bezemeli, el yapımı.

4- Küp, amorf gövde parças1, 7.5 YR 7/4 mat portakal renginde, yoğun kum katkıl1, taşçıklı, kötü pişirilmiş, kalın cidarlı, el yapımı.

5- Küp, amorf gövde parças1, 7.5 YR 7/6 portakal renginde, kum ve mika katkılı, taşçıklı, kötü pişirilmiş, el yapımı.

6- Kulp parçası, 7.5 YR 7/2 açık gri renkte astarlı, kum ve saman katkıl1, dış yüzeyi oluk bezemeli.

7- Kulp parçası, 5 YR 8/4 mat portakal renginde astarl1, kum ve kireç katkıl1, kötü pişirilmiş, dış yüzeyi oluk bezemeli. 
Fig. 6: Pınarkolu Mevkii - Sivritepe Arkeolojik Yerleşimi

1- Küp, ağız kenarı, Ç: $32 \mathrm{~cm}, \mathrm{Y}: 7 \mathrm{~cm}, 10$ YR 8/2 açık gri renkte astarlı, kum katkılı, çok iyi pişirilmiş, kalın ağız kenarlı, çark yapımı.

2- Kadeh, ağız kenarı, Ç: $12 \mathrm{~cm}, \mathrm{Y}: 3.8 \mathrm{~cm}, 7.5$ YR 5/8 açık kahverengi astarlı, kum, şamot ve mika katkı1ı, iyi pişirilmiş, açkı1ı, yavaş dönen çark yapımı.

3- Kadeh, ağız kenarı, Ç: $15 \mathrm{~cm}, \mathrm{Y}: 7.1 \mathrm{~cm}, 5$ YR 5/8 kırmızımsı kahverengi astarlı, ince cidarlı, açkıl1, kum, mika ve saman katkıl1, iyi pişirilmiş, çark yapımı.

4- Kâse, ağız kenarı, Ç: $30 \mathrm{~cm}, \mathrm{Y}: 4.3 \mathrm{~cm}, 10 \mathrm{YR}$ 6/6 portakal renginde astarl1, yoğun kum, mika ve ince saman katk1lı, açıılı, kötü pișirilmiş, çark yapımı.

5- Amorf gövde parças1, 7.5 YR 8/2 açık krem renginde astarlı, paralel bant bezemeli, ince cidarlı, yoğun mika ve ince saman katkılı, çark yapımı.

6- Amorf gövde parçası, 7.5 YR 7/2 açık kahverengimsi gri astarlı, siyah renkli paralel bant bezemeli, ince kum, saman ve mika katkıl1, kötü pişirilmiş, çark yapımı.

7- Kulp parçası, 7.5 YR 4/1 kahverengimsi gri renkte, kötü pişirilmiş, yoğun mika ve kum katk1l1.

Fig. 7: Kürdonun Bükü (1-2), Avşaroğlu Nekropol Alanı (3), Tepecik (4-6)

1- Küp, amorf gövde parçası, 7.5 YR 8/3 açık sarımsı portakal renginde astarlı, kaba kum ve saman katkılı, kötü pişirilmiş, el yapımı.

2- Küp, amorf gövde parçası, 10 YR $8 / 3$ açık kahverengi hamurlu, ince kum ve mika katkılı, orta derecede pişirilmiş, çark yapımı.

3- Kâse, ağız kenarı, Ç: $20 \mathrm{~cm}, Y: 6.4 \mathrm{~cm}, 7.5$ YR 8/2 açık gri renkte astarlı, ince kum ve ince saman katkılı, açkılanmış, iyi pişirilmiş, çark yapımı.

4- Kâse, ağı kenarı, Ç: $16 \mathrm{~cm}, \mathrm{Y}: 3.8 \mathrm{~cm}, 7.5$ YR 8/2 açık gri renkte astarlı, ince saman, kum ve mika katkılı, iyi pişirilmiş, çark yapımı.

5- Kadeh, ağız kenarı, Ç: $15 \mathrm{~cm}, \mathrm{Y}: 4.4 \mathrm{~cm}, 5$ YR 6/6 kırmızımsı kahverengi astarlı, ince kum ve saman katkılı, çok ince cidarlı, çok iyi pişirilmiş, çark yapımı.

6- Kulp parçası, 10 YR 4/1 kahverengimsi gri renkte, yoğun mineral ve mika katkıl1, iyi pişirilmiş, baskı bezemeli.

\section{Fig. 8: Örentepe (1-7), Sarılık Tepe (8)}

1- Kâse, ağız kenarı, Ç: $15 \mathrm{~cm}, \mathrm{Y}: 2.9 \mathrm{~cm}, 5$ YR 7/6 kırmızımsı kahverengi hamur renginde astarlı, taşçıklı, kum ve çok az mika katkılı, kötü pişirilmiş, yavaş dönen çark yapımı.

2- Kadeh, ağız kenarı, Ç: $10 \mathrm{~cm}, \mathrm{Y}: 3.7 \mathrm{~cm}, 5$ YR 7/6 kırmızımsı kahverengi hamur renginde astarlı, ince saman, kum ve çok az mika katkıl1, orta derecede pişirilmiş, çark yapımı.

3- Çanak, ağız kenarı, Ç: $14 \mathrm{~cm}$. Y: $4.3 \mathrm{~cm}, 5$ YR 7/6 kırmızımsı kahverengi hamurlu, kum, çok az mika ve ince saman katkılı, iyi pişirilmiş, çark yapımı.

4- Küp, ağız kenarı, Ç: $20 \mathrm{~cm}, \mathrm{Y}: 4.7 \mathrm{~cm}, 5$ YR 7/4 kırmızımsı kahverengi hamur renginde astarlı, kum, kireç ve çok az mika katkılı, kötü pişirilmiş, yavaş dönen çark yapımı.

5- Amorf parça, 2.5 YR 5/8 kırmızımsı kahverengi astarlı, mika ve kum katkılı, açkılı, iyi pişirilmiş, el yapımı.

6- Amorf gövde parçası, 2.5 YR 6/8 kırmızımsı kahverengi hamurlu, taşçıklı, ince saman ve mika katkıl1, orta derecede pişirilmiş, el yapımı.

7- Amorf gövde parças1, 2.5 YR 6/4 grimsi kahverengi astarl1, mika, kum ve saman katkıl1, açk1lı, kötü pișirilmiș, el yapımı.

8- Küp, amorf gövde parçası, 5 YR 7/6 sarımsı portakal renginde hamurlu, kaba kum ve saman katkılı, şerit kabartma bezemeli, çok iyi pişirilmiş, yavaş dönen çark yapımı. 
Fig. 9: Beypınarı Tepe (1-5), Kilise Tepe (6-8)

1- Küp, ağız kenarı, Ç: $36 \mathrm{~cm}, \mathrm{Y}: 7.2 \mathrm{~cm}, 7.5$ YR 7/2 kahverengimsi gri astarlı, yoğun kum, şamot, mika ve saman katkılı, açkı11, kötü pişirilmiş, el yapımı.

2- Küp, amorf gövde parçası, 7.5 YR 5/8 kırmızımsı kahverengi astarlı, açk11, kaba kum, mika ve ince saman katkılı, orta derecede pişirilmiş, parmak baskı bezemeli, el yapımı.

3- Küp, amorf gövde parçası, 7.5 YR 5/8 kırmızımsı kahverengi astarlı, parmak baskı bezemeli, kötü pişirilmiş, kaba kum, şamot ve mika katkılı, açkılanmış, el yapımı.

4- Amorf gövde parçası, 7.5 YR 8/2 açık gri renkte astarlı, kum, mineral ve mika katkılı, orta derecede pişirilmiş, kabartma şerit bezemeli, açkı1lı, el yapımı.

5- Amorf gövde parçası, 7.5 YR 6/4 kırmızımsı kahverengi astarlı, kum ve mika katkılı, baskı bezemeli, iç yüzeyi pişirmeden kaynaklı siyah alacalı, orta derecede pişirilmiş, el yapımı.

6- Kulp Parçası, 2.5 YR 7/4 mat kırmızımsı kahverengi astarlı, mika, kireç, kum ve saman katkılı, taşçıklı, orta derecede pişirilmiş, oluk bezemeli.

7- Amorf gövde parçası, 2.5 YR 6/6 kırmızımsı kahverengi astarlı, saman, kireç ve mika katkıl1, orta derecede pişirilmiş, el yapımı.

8- Küp, amorf gövde parçası, 2.5 YR 7/8 kırmızımsı kahverengi astarlı, yoğun mika katkılı, kötü pişirilmiş, açkıllı, kabartma bant bezemeli, yavaş dönen çark yapımı.

Fig. 10: Seyituşağı Kale Arkeolojik Alanı (1-4), Meydan Kalesi (5-9)

1- Kâse, ağız kenarı, Ç: $15 \mathrm{~cm}$ Y: $2.3 \mathrm{~cm}, 7.5$ YR 8/6 açık sarımsı portakal renginde astarlı, ince kum, saman ve mika katkılı, açkılanmış, orta derecede pişirilmiş, çark yapımı.

2- Kâse, ağız kenarı, Ç: 15 cm, Y: 3.4 cm, 7.5 YR 7/6 açık kahverengi astarlı, yoğun mika ve mineral katkılı, ince cidarlı, pişirmeden kaynaklı iç yüzeyi siyah alacalı, orta derecede pişirilmiş, çark yapımı.

3- Kâse, ağız kenarı, Ç: $15 \mathrm{~cm}, \mathrm{Y}: 1.4 \mathrm{~cm}, 7.5$ YR 8/6 açık sarımsı portakal hamur renginde astarlı, ince saman katkılı, taş̧̧ıklı, iyi pişirilmiş, el yapımı.

4- Kavanoz, ağız kenarı, Ç: $15 \mathrm{~cm}, \mathrm{Y}: 3.8 \mathrm{~cm}$, dış yüzeyi pişirmeden kaynaklı 7.5YR 2/1 siyah, iç yüzeyi 7.5 YR 5/8 kırmızımsı kahverengi astarlı, ince saman ve mika katkılı, taşçıklı, açkılanmış, orta derecede pişirilmiş, el yapımı.

5- Kâse, ağız kenarı, Ç: $15 \mathrm{~cm}, \mathrm{Y}: 5 \mathrm{~cm}, 5$ YR 7/6 açık sarımsı portakal renginde, taşçıklı, mika katkılı, orta derecede pişirilmiş, yavaş dönen çark yapımı.

6- Amorf gövde parças1, 2.5 YR 6/8 kırmızımsı kahverengi hamurlu, taşçıklı, ince saman ve mika katkılı, memecik şeklinde yumru bezemeli, orta derecede pişirilmiş, el yapımı.

7- Amorf parça, 2.5 YR 6/8 portakal renginde astarlı, bezemeli, kum ve kireç katk1lı, kötü pişirilmiş, taşçıklı, el yapımı.

8- Küp, ağız kenarı, Ç: $42 \mathrm{~cm}, Y: 11 \mathrm{~cm}, 5$ YR 7/6 kırmızımsı kahverengi hamur renginde astarlı, orta derecede pişirilmiş, taşçıklı ve saman katkılı, ağız kenarı ve boynu üç sıra halinde parmak baskı bezemeli, el yapımı.

9- Küp, ağız kenarı, Ç: $42 \mathrm{~cm}, \mathrm{Y}: 9.1 \mathrm{~cm}, 5$ YR 7/6 kırmızımsı kahverengi hamur renginde astarlı, taş̧̧ıklı, yoğun kum ve saman katkılı, ağız kenarı parmak baskı bezemeli, el yapım1.

\section{Fig. 11: Cihan Kalesi}

1- Kâse, ağız kenarı, Ç: $15 \mathrm{~cm}, \mathrm{Y}: 5.3 \mathrm{~cm}, 5$ YR 8/2 açık gri renkte astarlı, ince kum, saman ve mika katkılı, çark yapımı.

2- Kâse, ağız kenarı, Ç: $20 \mathrm{~cm}, \mathrm{Y}: 2.8 \mathrm{~cm}, 5$ YR 8/4 mat portakal renginde astarlı, ince kum ve çok az saman katkı1ı, kötü pişirilmiş, çark yapımı. 
3- Kâse, ağız kenarı, Ç: $18 \mathrm{~cm}, \mathrm{Y}: 3.3 \mathrm{~cm}, 5$ YR 7/6 kırmızımsı kahverengi astarl1, açkılanmış, ince kum, mika ve ince saman katkılı, iyi pişirilmiş, çark yapımı.

4- Kâse, ağız kenarı, Ç: $20 \mathrm{~cm}, \mathrm{Y}: 4.1 \mathrm{~cm}, 2.5$ YR 6/8 kırmızımsı kahverengi astarlı, açkılı, ince kum ve şamot katkılı, paralel çizi bezemeli, ince cidarlı, kötü pişirilmiş, çark yapımı.

5- Küp, ağız kenarı, Ç: $22 \mathrm{~cm}, \mathrm{Y}: 5.3 \mathrm{~cm}, 5$ YR 7/6 kırmızımsı kahverengi astarlı, taşçıklı, kum, mika ve saman katkıl1, kötü pişirilmiş, el yapımı.

6- Kavanoz, ağız kenarı, Ç: $20 \mathrm{~cm}, \mathrm{Y}: 4.6 \mathrm{~cm}, 5$ YR 7/4 açık kahverengi, hamur renginde astarlı, taşçıklı, kireç katkılı, iyi pişirilmiş, tırnak baskı ve paralel bantlardan oluşan çizi bezemeli, yavaş dönen çark yapımı.

7- Kulp parçası, 5 YR 7/6 kırmızımsı kahverengi astarlı, taşçıklı, orta derecede pişirilmiş, oluk bezemeli, el yapımı.

8- Kulp parçası, 5 YR 7/6 kırmızımsı kahverengi hamurlu, taşçıklı, şamot katkılı, kaba yapılmış, orta derecede pişirilmiş, el yapımı.

9- Kulp parçası, 5 YR 8/2 açık gri renkte astarlı, yoğun kum, kireç, mika ve ince saman katkılı, orta derecede pişirilmiş, parmak baskı bezemeli, el yapımı.

10- Amorf gövde parçası, 2.5 YR 6/8 kırmızımsı kahverengi hamurlu, taşçıklı, açkılanmış, iyi pişirilmiş, el yapımı.

\section{Fig. 12: Aşağıköy Kalebaşı (1-4), Üçgöze Ziyaret Tepe (5)}

1- Kâse, ağız kenarı, Ç: $16 \mathrm{~cm}, \mathrm{Y}: 5.1 \mathrm{~cm}, 2.5$ YR 6/8 kırmızımsı kahverengi, hamur renginde astarlı, açkılanmış, taşçıklı, çok az mika katkılı, orta derecede pişirilmiş, çark yapımı.

2- Kâse, ağız kenarı, Ç: $12 \mathrm{~cm}, \mathrm{Y:} 3.4 \mathrm{~cm}, 5$ YR 6/6 kahverengi, hamur renginde astarl1, taş̧̧ılı, mika katkılı, orta derecede pişirilmiş, açkılanmıș, el yapımı.

3- Kâse, ağız kenarı, Ç: $14 \mathrm{~cm}, \mathrm{Y}: 2.7 \mathrm{~cm}, 5$ YR 6/6 kahverengi hamurlu, taşçıklı, iyi pişirilmiş, el yapımı.

4- Amorf gövde parças1, 2.5 YR 5/6 kahverengi hamurlu, taşçıklı, mika ve saman katk1l, pişirmeden kaynaklı siyah alacalı, orta derecede pişirilmiş, dalgalı yivli bezemeli, el yapımı.

5- Kâse, ağız kenarı, Ç: $20 \mathrm{~cm}, \mathrm{Y}: 4.2 \mathrm{~cm}, 2.5$ YR 7/3 kırmızımsı gri renkte, taş̧̧ıklı, yoğun kum, mika ve saman katkılı, kötü pişirilmiş, çark yapımı.

\section{Kaynakça ve Kısaltmalar}

Anastasio, S., Atlas of the Assyrian Pottery of the Iron Age, SUBARTU XXIV, Brepols, Turnhout 2010.

Bartl, K., "Some Remarks on Early Iron Age in Eastern Anatolia", Anatolica XXI, 1995, s. 205-212.

Bartl, K., "Eastern Anatolia in the Early Iron Age", R. Eichmann, H. Parzinger (yay.) Migration und Kulturtransfer: der Wandel vorder - und zentralasiatischer Kulturen im Umbruch vom 2. zum 1. vorchristlichen Jahrtausend: Akten des Internationalen Kolloguiums, Berlin, 23. Bis 26. November 1999, Habelt, Bonn 2001, s. 383-410.

Belli, O. ve E. Konyar, Doğu Anadolu Bölgesi'nde Erken Demir Çağı Kale ve Nekropolleri, N. Başgelen (yay.) Arkeoloji ve Sanat Yayınları, İstanbul 2003. 
Bilgi, Ö., “Köşkerbaba Kazıları 1979”, II. Kazı Sonuçları Toplantısı 1980, s. 113119.

Bilgi, Ö., "Köşkerbaba Höyük Kazısı 1980 Yılı Sonuçları”, III. Kazı Sonuçları Toplantist 1981, s. 83-86.

Bilgi, Ö., "Köşkerbaba Höyük 1981 Dönemi Kazıları", IV. Kazı Sonuçları Toplantsst 1982, s. 89-93.

Bilgi, Ö., "Köşkerbaba Höyüğü Kazıları", V. Kazı Sonuçları Toplantısı 1983, s.: 113-116.

Bilgi, Ö., “1983 Dönemi Malatya-Köşkerbaba Höyük Kurtarma Kazıları”, VI. Kazı Sonuçları Toplantısı 1984, s. 49-54.

Bilgi, Ö., “1984 Dönemi Malatya-Köşkerbaba Höyük Kurtarma Kazıları”, VII. Kazı Sonuçları Toplantısı 1985, s. 143-149.

Bilgi, Ö., "Köşkerbaba Höyük Kazısı, 1978”, Aşağı Fırat Projesi 1978-1979 Çalışmaları, Orta Doğu Teknik Üniversitesi Aşağı Fırat Projesi Yayınları 1/3, Ankara 1987, s. 189-216, Lev. 115-131.

Bilgi, Ö., "Köşkerbaba Höyük Kazısı 1979”, Aşağı Fırat Projesi 1978-1979 Çalışmaları, Orta Doğu Teknik Üniversitesi Aşağı Fırat Projesi Yayınları 1/3, Ankara 1987, s. 217-248, Lev. 132-150.

Blaylock, S. R., D. H. French ve G. D. Summers, "The Adiyaman Survey: An Interim Report", Anatolian Studies 40, 1990, s. 81-135.

Blaylock, S. R., "Iron Age Pottery from Tille Höyük, South-Eastern Turkey", A. Hausleiter, A. Reiche (yay.) Iron Age Pottery in Northern Mesopotamia, Northern Syria und South-Eastern Anatolia, Ugarit-Verlag, Münster 1999, s. 263-286.

Bryce, T., Letters of the Great Kings of the Ancient Near East. The Royal Correspondence of the Late Bronze Age, Roudledge, London, New York 2003.

Bryce, T., The World of the Neo-Hittite Kingdoms: A Political and Military History, Oxford University Press, New York 2012.

Çilingiroğlu, A., "Urartu'da Toplu Nüfus Aktarımları", Anadolu Araştırmaları IX, 1983, s. 311-317.

D'Agostino, A., "The Assyrian-Aramaean Interaction in the Upper Khabur: The Archaeological Evidence from Tell Barri Iron Age Layers", Syria 86, 2009, s. 17-41.

Di Nocera, G. M., "2003 Archaeological Survey in the Malatya Territory", 22. Araştırma Sonuçları Toplantısı 2004, s. 325-336.

Di Nocera, G. M., "Settlements, population and landscape on the Upper Euphrates between V and II millennium BC. Results of the Archaeological Survey Project 
2003-2005 in the Malatya Plain", Proceedings of the 5th International Congress on the Archaeology of the Ancient Near East, April 3-8 2006, Madrid 2008, s. 633-645.

Dönmez, S. "2017 Malatya Yüzey Araştırması: Erken ve Orta Demir Çağ1 Araştırmalarına Yeni Katkılar”, Tarih Araştırmaları Dergisi 38/65, 2019, s. 43-82.

Drake, B. L., "The influence of climatic change on the Late Bronze Age Collapse and the Greek Dark Ages", Journal of Archaeological Science 39, s. 1862 1870 .

Durbin, G. E. S., "Iron Age Pottery from the provinces of Tokat and Sivas", Anatolian Studies 21, 1971, s. 99-124.

Duru, R., “Değirmentepe Höyüğü Kazısı, 1973”, Keban Projesi 1973 Çalışmaları, Orta Doğu Teknik Üniversitesi Keban Projesi Yayınları I/6, Ankara 1979, s. 13-24, Lev. 1-6.

Elayi, J., Sargon II, King of Assyria, SBL Press, Atlanta 2017.

Emre, K., “The Urartian Pottery from Altıntepe”, Belleten 33, 1969, s. 291-301.

Erdem, A. Ü., "Regional Variations in Iron Age Grooved Pottery in Eastern Anatolia" A. Çilingiroğlu, A. Sagona (yay.) Anatolian Iron Ages 7, Peeters, Leuven, Paris, Walpole, MA 2012, s. 113-130.

Esin, U., “1979 Değirmentepe Kazıları”, II. Kazı Sonuçları Toplantısı 1980, s. 9199.

Esin, U., “1980 Yılı Değirmentepe (Malatya) Kazısı Sonuçları”, III. Kazı Sonuçları Toplantısı 1981, s. 39-41

Esin, U., "Değirmentepe (Malatya) Kazısı 1981 Yılı Sonuçları", IV. Kazı Sonuçları Toplantısl 1982, s. 39-48.

Esin, U., G. Arsebük, “Değirmentepe Kazısı”, V. Kazı Sonuçları Toplantısı 1983, s. 71-80.

Esin, U., "Değirmentepe (Malatya) Kurtarma Kazısı 1983 Yılı Raporu”, VI. Kazı Sonuçları Toplantısı 1984, s. 11-30.

Esin, U., S. Harmankaya, “1984 Değirmentepe (Malatya) Kurtarma Kazısı”, VII, Kazı Sonuçları Toplantısı 1985, s. 53-86.

Esin, U., S. Harmankaya, “1985 Değirmentepe (Malatya İmamlı Köyü) Kurtarma Kazısı”, VIII. Kazı Sonuçları Toplantısı 1986, s. 95-137.

Finné, M., K. Holmgren, H. S. Sundqvist, E. Weiberg, M. Lindblom, "Climate in the eastern Mediterranean, and adjacent regions, during the past 6000 years - A review", Journal of Archaeological Science 38, s. 3153-3173. 
Frangipane, M., F. Di Filippo, F. Manuelli ve L. Mori, "Collapse or Transformation? Regeneration and innovation at the turn of the first millennium BC at Arslantepe, Turkey", Antiquity 92/362, 2018, s. 1-7.

French, D., “Tille”, VIII. Kazı Sonuçları Toplantısı I, 1986, s. 205-212.

Güneri, A. S., "Cultural Connections between Anatolia and Caucasus-Central Asia during the Late Bronze - Early Iron Age", Anatolia Antiqua X, 2002, s. 11-77.

Hauptmann, H., "Norşuntepe Kazısı, 1969” Keban Projesi 1969 Çalışmaları, Orta Doğu Teknik Üniversitesi Keban Projesi Yayınları, I/2, Ankara 1971, s. 71-79, Lev. 47-61.

Hauptmann, H., "Norşuntepe Kazıları, 1970” Keban Projesi 1970 Çalışmaları, Orta Doğu Teknik Üniversitesi Keban Projesi Yayınları, I/3, Ankara 1972, s. 87101, Lev. 57-80.

Hauptmann, H., "Norşuntepe Kazıları, 1971” Keban Projesi 1971 Çalışmaları, Orta Doğu Teknik Üniversitesi Keban Projesi Yayınları, I/4, Ankara 1974, s. 71-82, Lev. 68-84.

Hauptmann, H., “Norşuntepe Kazıları, 1972” Keban Projesi 1972 Çalışmaları, Orta Doğu Teknik Üniversitesi Keban Projesi Yayınları, I/5, Ankara 1976, s. 41-59, Lev. 29-62.

Hauptmann, H., "Norşuntepe Kazıları, 1974”, Keban Projesi 1974-1975 Çalışmaları, Orta Doğu Teknik Üniversitesi Keban Projesi Yayınları I/7, Ankara 1982, s. 15-70, Lev. 13-52.

Hausleiter, A., Neuassyrische Keramik im Kerngebiet Assyriens. Chronologie und Formen, Harrassowitz Verlag, Wiesbaden 2010.

Heltzer, M., The Suteans, Istituto Universitario Orientale Seminario Di Studi Asiatici, Series Minor XIII, Naples 1981.

Işıklı, M. ve A.Ü. Erdem "A group of Early Iron Age pottery from the Erzurum Region", Archäologische Mitteilungen aus Iran und Turan 41, 2009, s. 249 268.

Karadoğan, S., "Kuruluş Yeri Açısından Malatya Şehri ve Yakın Çevresinin Jeomorfolojisi”, Fırat Üniversitesi Sosyal Bilimler Dergisi 11/1, 2001, s. 27 56.

Khatchadourian, L., "The Iron Age in Eastern Anatolia", S.H. Steadman, G. McMahon (yay.) Ancient Anatolia (10,000-323 B.C.E), Oxford University Press, New York 2011, s.464-499.

Konyar, E., Doğu Anadolu Erken Demir Çă̆ı Kültürü: Arkeolojik Kazı ve Yüzey Araştırmaları Bulgularının Değerlendirilmesi, İstanbul Üniversitesi Sosyal Bilimler Enstitüsü Tarih Anabilim Dalı Eskiçağ Tarihi Bilim Dalı, Yayımlanmamış Doktora Tezi. İstanbul 2004. 
Köroğlu, K., “Demir Çağı'nda Yukarı Dicle Bölgesi”, Anadolu Araştırmaları 16, 2002, s. 449-475.

Köroğlu, K., "The Transition from Bronze Age to Iron Age in Eastern Anatolia", B. Fischer, H. Genz, E. Jean ve K. Köroğlu (yay.), Identifying Changes: The Transition from Bronze to Iron Ages in Anatolia and Its Neighbouring Regions. Proceedings of the International Workshop, Istanbul, November 8-9, 2002. İstanbul 2003, s. 231-241.

Köroğlu, K., "Conflict and Interaction in the Iron Age: The Origins of UrartianAssyrian Relations", European Journal of Archaeology 18, 2015, s. 111-127.

Liverani, M., "Melid in the Early and Middle Iron Age: Archaeology and History" G. Galil, A. Gilboa, A. M. Maeir ve D. Kahn (yay.) The Ancient Near East in the $12^{\text {th }}-10^{\text {th }}$ centuries BCE. Culture and History, Ugarit-Verlag, Münster 2012, s. 327-344.

Liverani, M., The Ancient Near East. History, society and economy, Transl. S. Tabatabai, Roudledge, London, New York 2014.

Mazzoni, S., "Syria and the periodization of the Iron Age: A cross-cultural perspective", G. Bunnens (yay.) Essays on Syria In the Iron Age, Louvain, Ancient Near Eastern Studies, supplement 7, 2000, s. 31-59.

Manuelli, F., "Malatya-Melid between the Late Bronze and Iron Age. Continuity and Change at Arslantepe during $2^{\text {nd }}$ and $1^{\text {st }}$ Millennium BC: Preliminary Observations on the Pottery Assemblages" K. Strobel (yay.) Empires after the Empire. Anatolia, Syria and Assyria after Šuppiluliuma II. Eothen XVII, LoGisma, Firenze 2011, s. 61-86.

Manuelli, F., "From the Early to the Middle Iron Age: Development of the Pottery Inventories from the New Excavations at Arslantepe" Proceedings of the 7th International Congress on the Archaeology of the Ancient Near East 2012a, s. 447-460.

Manuelli, F., "A View from the East. Arslantepe and the Central Anatolian World during the Late Bronze and Iron Ages: Interactions and Local Development", ORIGINI XXXIV 2012b: 361-374.

Manuelli, F., "Pottery as an Indicator of Changing Interregional Relations in the Upper Euphrates Valley. The Case of the Late Bronze-Iron Age Assemblages from Arslantepe/Malatya", K. A. Yener (yay.) Across the Border: The Late Bronze-Iron Age Relations Between Syria and Anatolia, Peeters, Leuven, Paris, Walpole, MA 2013, s. 373-392.

Marro, C. ve A. Özfirat, "Pre-classical survey in eastern Turkey. First preliminary report. The Ağrı Dağ (Mount Ararat) Region”, Anatolia Antiqua XI, 2003, s. 385-422. 
Müller, Ü., "Die eisenzeitliche Keramik des Lidar Höyük", A. Hausleiter, A. Reiche (yay.) Iron Age Pottery in Northern Mesopotamia, Northern Syria und SouthEastern Anatolia, Ugarit-Verlag, Münster 1999, s. 403-434.

Oggiano, I., "Cataloguistics: The Experience at Tell Afis, Syria”, A. Hausleiter \& A. Reiche (yay.) Iron Age Pottery in Northern Mesopotamia, Northern Syria und South-Eastern Anatolia, Ugarit-Verlag, Münster 1999, s. 377-402.

Ökse, T., Mitteleisenzeitliche Keramik Zentral-Ostanatoliens mit dem Schwerpunkt Karakaya Stauseegebiet am Euphrat, D. Reimer Verlag, Berlin 1988.

Özdoğan, M. Lower Euphrates Basin 1977 Survey, Lower Euphrate Project Publications I/2. Istanbul 1977.

Parker, A., "Norheastern Anatolia: On the Periphery of Empires", Anatolian Studies 49, 1999 s. $133-141$.

Reiche, A., "Iron Age pottery from Tell Rad Shaqrah (North-East Syria)", A. Hausleiter, A. Reiche (yay.) Iron Age Pottery in Northern Mesopotamia, Northern Syria und South-Eastern Anatolia, Ugarit-Verlag, Münster 1999, s. 231-259.

RIMA: The Royal Inscription of Mesopotamia: Assyrian Periods, Toronto, Buffalo, and London: University of Toronto Press.

RIMA 2: A.K. Grayson, Assyrian Rulers of the Third and Second Millennia BC I (1114-859 BC), 1991.

Roaf, M. ve A. Schachner, "The Bronze Age to Iron Age transition in the upper Tigris region: new information from Ziyaret Tepe and Giricano" A. Çilingiroğlu, G. Darbyshire (yay.) Anatolian Iron Ages 5, London 2005, s. 115 124.

Russell, H. F., Pre-Classical Pottery of Eastern Anatolia. Based on a survey by Charles Burney of sites along the Euphrates and around Lake Van, British Institute of Archaeology at Ankara, Monograph No. 2, BAR International Series 85, Oxford 1980

Sagona, A., "Remarks on the East Anatolian Iron Age" A. Çilingiroğlu, A. Sagona (yay.) Anatolian Iron Ages 7. Proceedings of the Seventh Anatolian Iron Ages Colloquium Held at Edirne, 19-24 April 2010, Peeters, Leuven-Paris-Walpole, MA 2012, s. 253-267.

Sagona, A. ve P. Zimansky, Ancient Turkey, Roudledge World Archaeoology, London, New York 2009.

Schachner, A., "From the Bronze to the Iron Age: Identifying Changes in the Upper Tigris Region. The Case of Giricano", B. Fischer, H. Genz, E. Jean ve K. Köroğlu (yay.) Identifying Changes: The Transition from Bronze to Iron Ages in Anatolia and its Neighbouring Regions, Türk Eskiçağ Bilimleri Enstitüsü, İstanbul 2003, s. 151-163. 
Schmidt, C., "Die Keramik der Areale A-F in Kar-Tukulti Ninurta" A. Hausleiter, A. Reiche (yay.) Iron Age Pottery in Northern Mesopotamia, Northern Syria und South-Eastern Anatolia, Ugarit-Verlag, Münster 1999, s. 61-90.

Schneider, E., "Die eisenzeitliche Keramik von Tell Sheikh Hassan (Syria)", A. Hausleiter, A. Reiche (yay.) Iron Age Pottery in Northern Mesopotamia, Northern Syria und South-Eastern Anatolia, Ugarit-Verlag, Münster 1999, s. 325-346.

Serdaroğlu, Ü., 1975 Surveys in the Lower Euphrates Basin, Ankara 1977.

Sevin, V., “İmikuşağı Kazıları”, V. Kazı Sonuçları Toplantısı, 1983, s. 137-142.

Sevin, V. ve K. Köroğlu, “İmikuşağı Kazıları, 1984”, VI. Kazı Sonuçları Toplantısı, 1985, s. 163-180.

Sevin, V., "Elazığ-Bingöl İlleri Yüzey Araştırması, 1986”, V. Araştırma Sonuçları Toplantısı 1987, s. 1-44.

Sevin, V., "Elazığ-Bingöl Yüzey Araştırması, 1987”, VI. Araştırma Sonuçları Toplantısi 1988, s. 451-500.

Sevin, V., "The Early Iron Age in the Elazığ Region and the Problem of the Mushkians", Anatolian Studies 41,1991, s. 87-97.

Stronach, D., Pasargadae: A Report on the Excavations, 1961-1963, Oxford 1978.

Summers, G. D., "Revisiting the end of the Late Bronze Age and the transition to the Early Iron Age at Tille Höyük", Iraq 71, 2010, s. 193-200.

Şenyurt, S. Y., Büyükardıç: Doğu Anadolu'da Bir Erken Demir Çă̆ Tepe Yerleşmesi /An Early Iron Age Hilltop Settlement in Eastern Anatolia, BaküTiflis-Ceyhan Ham Petrol Boru Hattı Projesi Arkeolojik Kurtarma Kazıları Yayınlar1 2 / Baku-Tbilisi-Ceyhan Crude Oil Pipeline Project Publications of Archaeological Salvage Excavations 2, Ankara 2005.

Şenyurt, Y., Y. Kamış ve A. Akçay, “Tasmasor Geç Demir Çă̆ı Çanak Çömlek Buluntuları", S. Y. Şenyurt (yay.) Tasmasor, Bilgin Kültür Sanat Yayınları, Ankara 2011, s. 117-258.

Taş, İ. ve S. F. Adalı, “Çivi Yazısı Geleneğinde Lullu Halkı”, KUBABA ArkeolojiSanat Tarihi-Tarih Dergisi 24 2015, s. 21-36.

Tekin, H., "Yatay Oluk Bezekli Bir Seramik Grubunun Ele Geçtiği Yeni Bir Merkez: Hakemi Use", Hacettepe Üniversitesi Edebiyat Fakültesi Dergisi 23/1, 2006, s. 151-172.

Tonbul, S. ve M. Siler, "Malatya Güneyinde Güneydoğu Torosların Jeomorfolojik Özellikleri” F. Arslan (yay.) Türkiye Coğrafyası Araştırmaları: Prof. Dr. Mesut Elibüyük'e Armağan, Pegem Akademi Yayınları, Ankara 2017, s. 463490. 
Winn, M. M., "The Early Iron Age" M. N. van Loon (yay.) Korucutepe: Final Report on the Excavations of the Universities of Chicago, California (Los Angeles) and Amsterdam in the Keban Reservoir, Eastern Anatolia 1968-1970, Vol. 3, North-Holland Publishing Company-Amsterdam, New York, Oxford 1980, s. 155-175, Lev. 51-61.

Vidal, J. "Sutean Warfare in the Amarna Letters", J. Vidal (yay.) Studies on War in the Ancient Near East: Collected Essays on Military History. Ugarit-Verlag, Münster 2010, s. 95-103.

Yakar, J. Anadolu'nun Etnoarkeolojisi: Tunç ve Demir Çağlarında Kırsal Kesimin Sosyo-Ekonomik Yapısı, Çev. S. H. Riegel, Homer Yayınları, İstanbul 2007.

Yiğitpaşa, D., “Arkeolojik Veriler Işığında Doğu Anadolu Geç Demir Çağı (M.Ö. 7.-4. Y.Y.) Çanak Çömleği”, Uluslararası Sosyal Araştırmalar Dergisi 8/37, 2015, s. 512-538. 
46

Sevgi DÖNMEZ
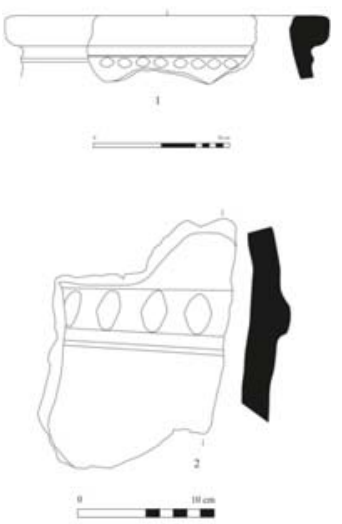

Fig. 1: Alibey Höyük

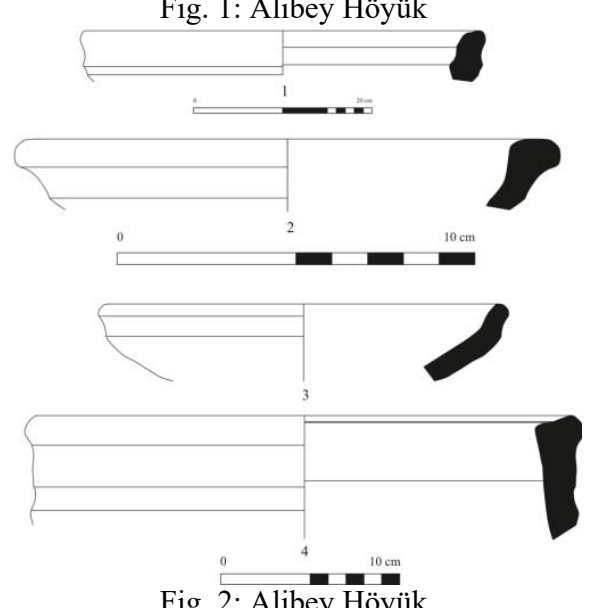

Fig. 2: Alibey Höyük

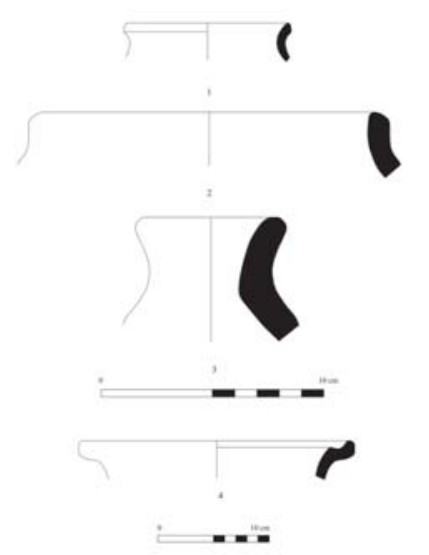

Fig. 3: Alibey Höyük 


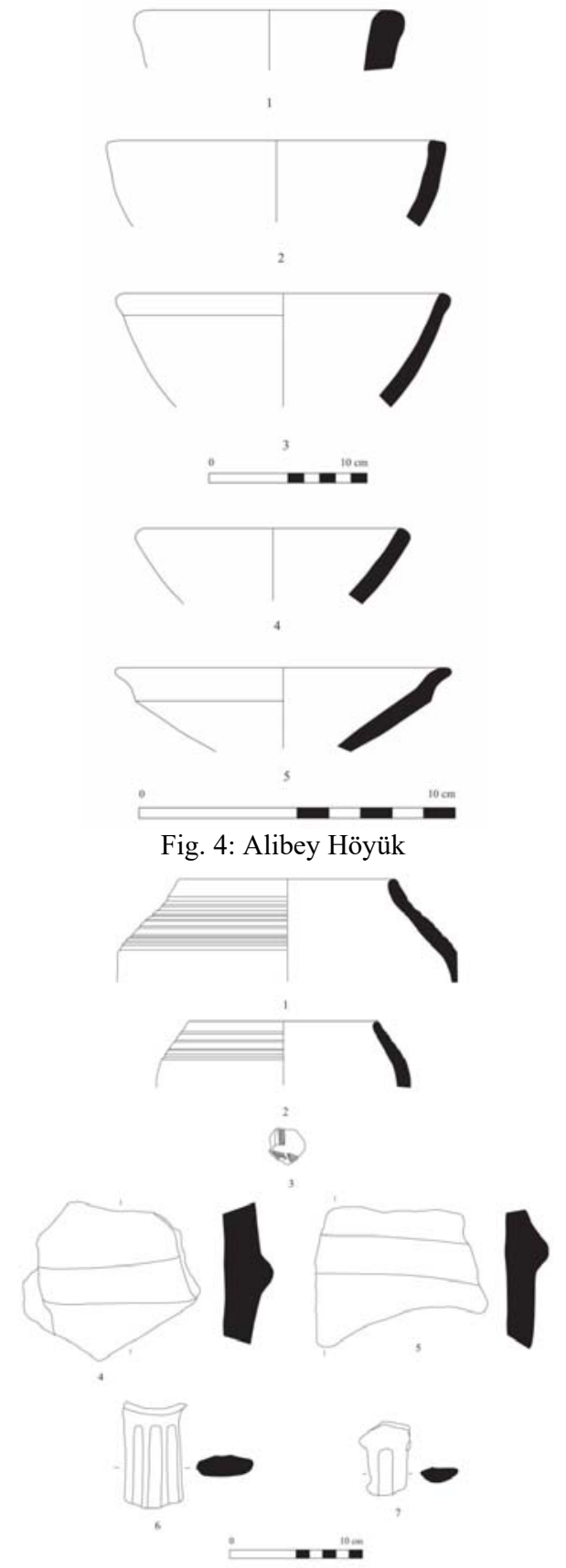

Fig. 5: Alibey Höyük 

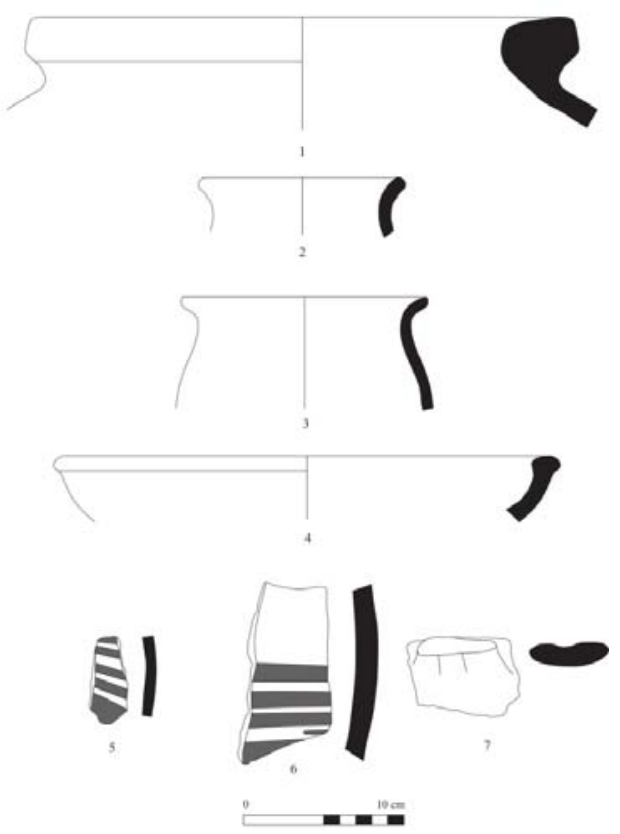

Fig. 6: Pınarkolu Mevkii Sivritepe
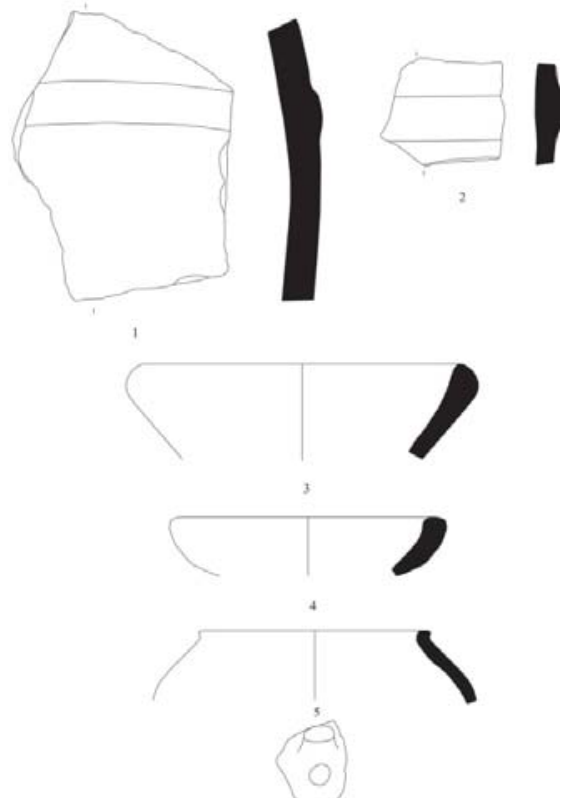

Fig. 7: Kürdonun Bükü (1-2); Avşaroğlu Nekropol Alanı (3); Tepecik (4-6) 


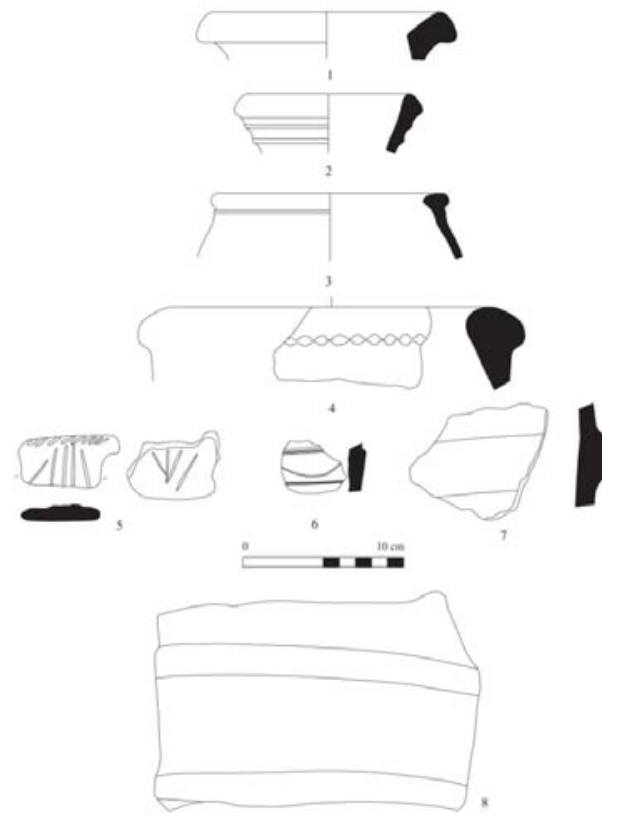

Fig. 8: Karahan Örentepe Höyük (1-7); Sarılık Tepe (8)

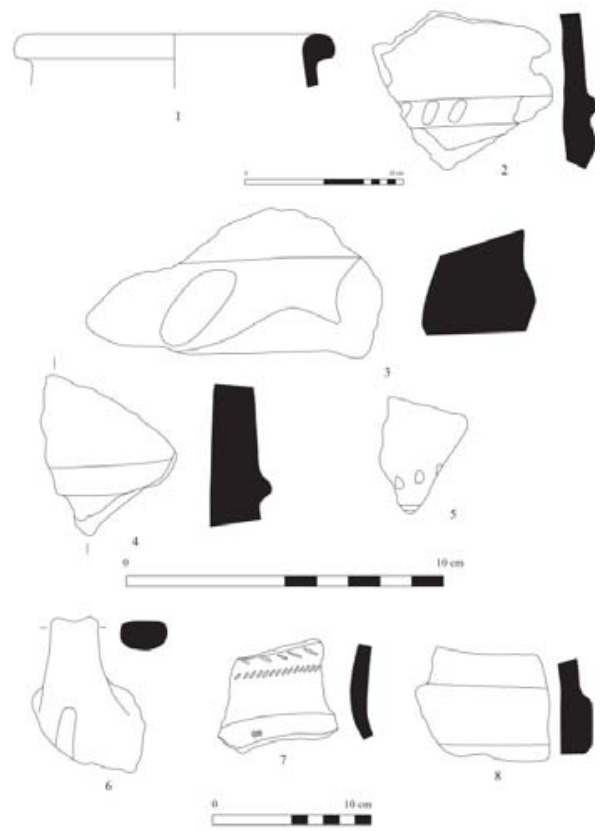

Fig. 9: Beypınarı Tepe (1-5); Kilise Tepe (6-8) 


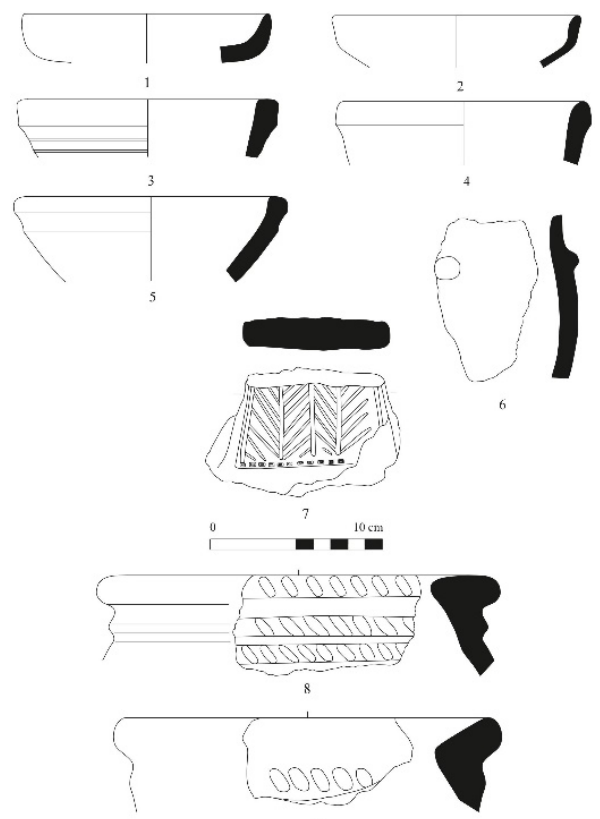

Fig. 10: Seyituşağı Kale Arkeolojik Yerleşimi (1-4); Meydan Kalesi (5-9)

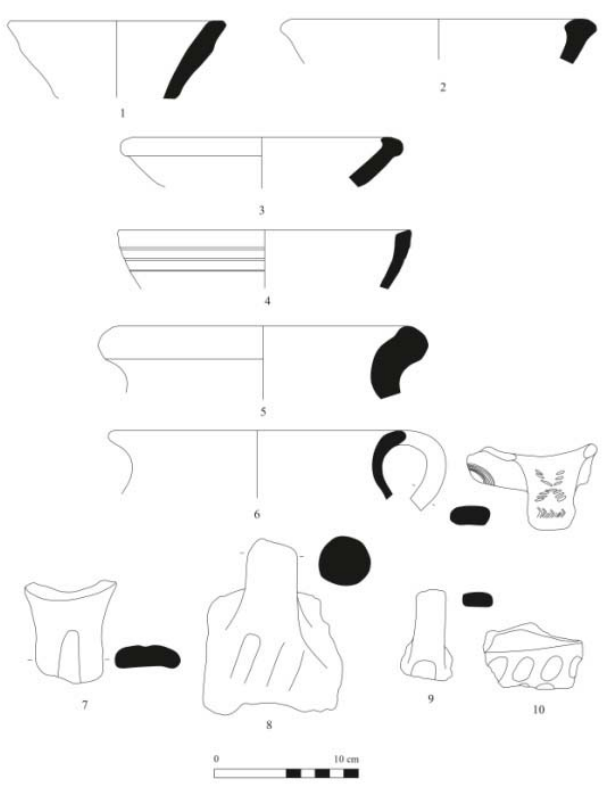

Fig. 11: Cihan Kalesi 


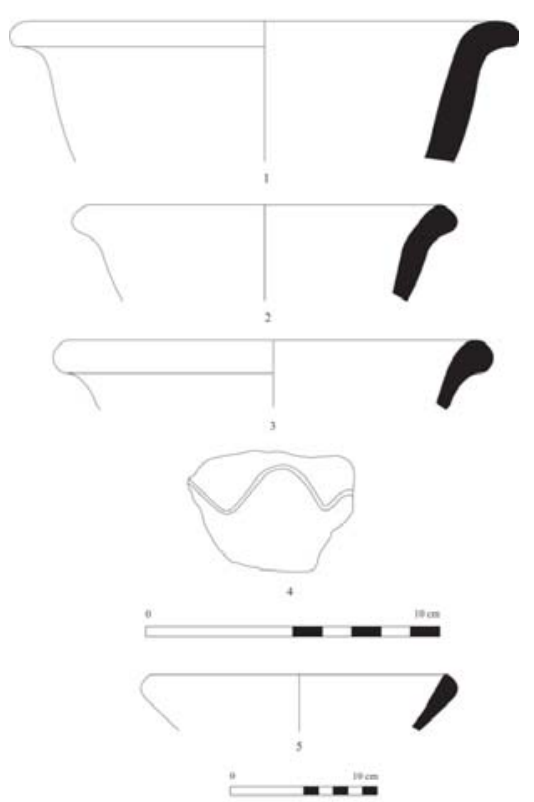

Fig. 12: Aşağıköy Kalebaşı (1-4); Üçgöze Köyü Ziyaret Tepe (5)

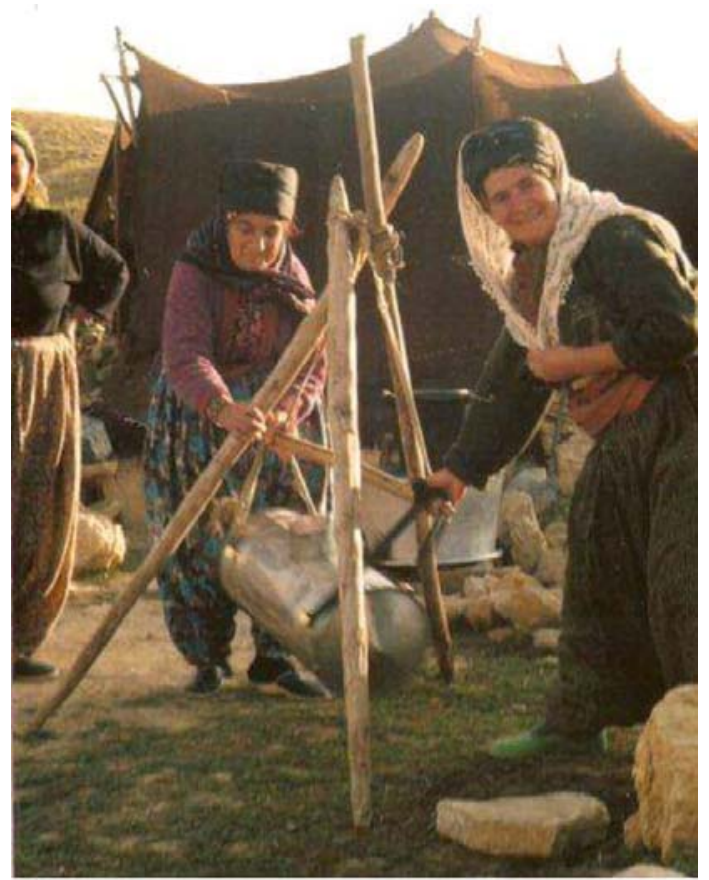

Fig. 13: Yarı göçebeler, Kömür Yaylası (Emine Dönmez’in izni ile) 


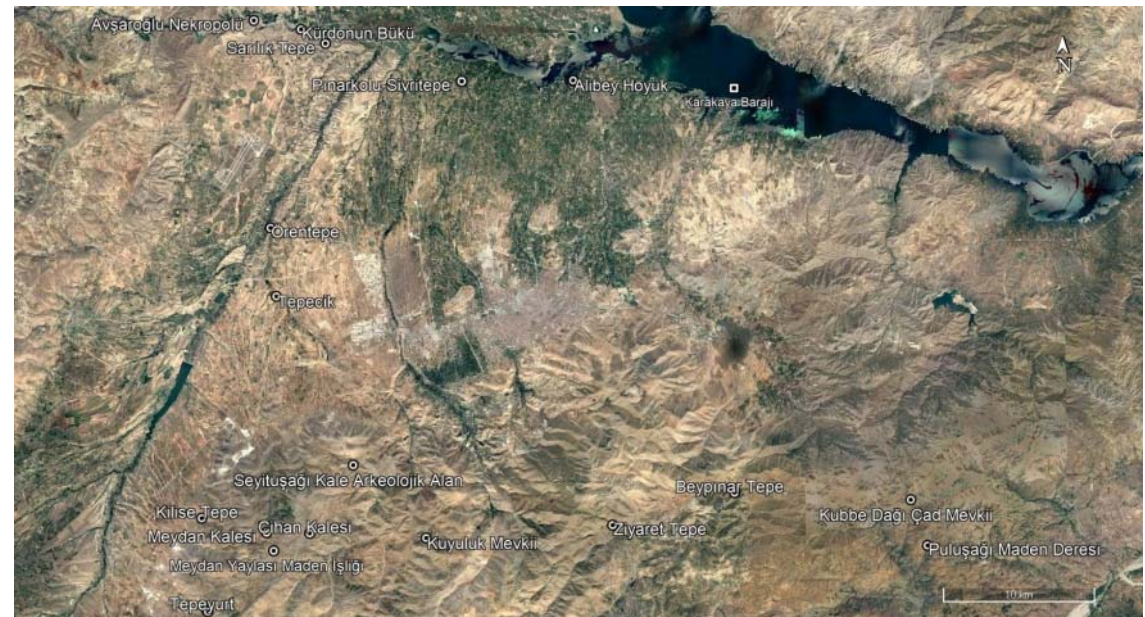

Fig. 14: Malatya Ovası ve Malatya Dağları'nın kuzeyinde yer alan Demir Çağı merkezleri ve maden işlik alanları

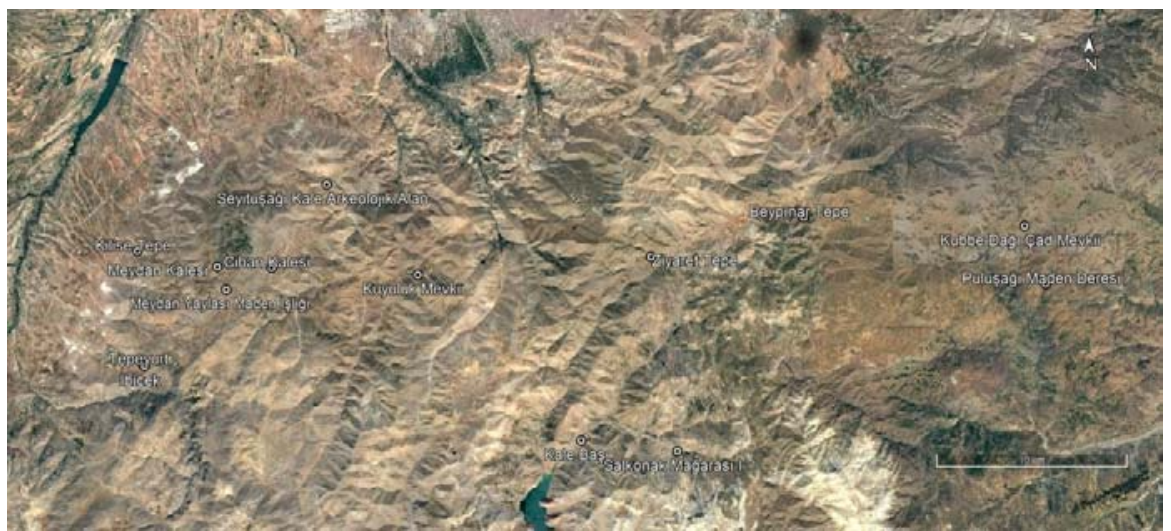

Fig. 15: Malatya Dağları'nda 2018 yılında tespit edilen Demir Çağı merkezleri ve demir madeni işlik alanları 